\title{
Distribution and Numbers of Three Globally Threatened Waterbird Species Wintering in Morocco: The Common Pochard, Marbled Teal, and White-Headed Duck
}

\author{
Asmaâ Ouassou $\mathbb{D}^{1},{ }^{1}$ Mohamed Dakki ${ }^{\mathbb{D}},{ }^{1}$ Mohammed-Aziz El Agbani, ${ }^{1}$ \\ Abdeljebbar Qninba $\mathbb{1}^{1}{ }^{1}$ and R'himou El Hamoumi $\mathbb{1}^{2,3}$ \\ ${ }^{1}$ Study Centre of Bird Migration, Geo-Biodiversity and Natural Patrimony Laboratory, \\ Department of Zoology and Animal Ecology, Scientific Institute, Mohammed V University in Rabat, Rabat 10106, Morocco \\ ${ }^{2}$ Laboratory of Ecology and Environment, Ben M'sik Faculty of Sciences, Hassan II University, Casablanca, Morocco \\ ${ }^{3}$ GREPOM/BirdLife Morocco, Salé, Morocco
}

Correspondence should be addressed to Asmaâ Ouassou; asmaa.ouassou@gmail.com

Received 3 August 2020; Revised 25 December 2020; Accepted 31 December 2020; Published 21 January 2021

Academic Editor: Marco Cucco

Copyright (c) 2021 Asmaâ Ouassou et al. This is an open access article distributed under the Creative Commons Attribution License, which permits unrestricted use, distribution, and reproduction in any medium, provided the original work is properly cited.

\begin{abstract}
Morocco plays a key role in the life of many migratory birds and their survival, thanks to the diversity and richness of its ecosystems. The International Waterbird Census (IWC) has been regularly implemented in Morocco since 1983. Thanks to this program, a large database on wintering waterbirds' populations has been collected. In this article, we summarize the wintering data of three globally threatened waterbirds: Aythya ferina, Marmaronetta angustirostris, and Oxyura leucocephala. The population of Aythya ferina, which is declining, is largely distributed in the country, in over a hundred wetlands, 26 of which verify the national importance criteria. Marmaronetta angustirostris has a stable trend over the years even though its population can know high annual fluctuations; it winters in more or less 50 wetlands, among which 18 host more than $1 \%$ of its regional population and 16 verify the criteria for national importance. On the contrary, Oxyura leucocephala, a globally endangered bird only encountered in a dozen wetlands, shows a moderate increase in its numbers; only two wetlands verify the Ramsar criterion 6, while a total of six can be considered of national importance. Furthermore, given the conservation statuses of these waterbirds and according to the Ramsar criterion 2, all their hosting sites are of international importance. The results presented in this paper are a crucial step for the adoption and implementation of adequate conservation measures for the species and their key sites. Nevertheless, comprehensive research and coordinated efforts on the factors (ecological and anthropogenic) influencing the species, at the national and international levels, are required for a better understanding of their populations' dynamics.
\end{abstract}

\section{Introduction}

Morocco is a North African country, with highly diversified ecosystems and coastlines along both Atlantic Ocean and Mediterranean Sea $[1,2]$. It is located at the crossroads of many bird migration routes between Europe and Tropical Africa, and its wetlands play a crucial role for thousands of birds as stopover, wintering, and breeding areas $[3,4]$. The country has ratified almost all international and regional agreements for the conservation of these birds and their habitats. In the context of the Ramsar Convention and the African-Eurasian Migratory
Waterbird Agreement, the country undertakes regular waterbird censuses that provide an appropriate basis for effective decision-making in their conservation. In fact, Morocco has been regularly participating, since 1983, in the International Waterbird Census (IWC), one of the largest biodiversity monitoring programs in the world, thanks to the coordination of the Study Centre of Bird Migration (in the Scientific Institute) and the collaboration of GREPOM/BirdLife Morocco, which provides the majority of field volunteers.

This article provides new syntheses on three globally threatened species of Anseriformes [5]: the White-headed 
Duck Oxyura leucocephala (Scopoli, 1769), an endangered bird [6], and two vulnerable species the Marbled Teal Marmaronetta angustirostris (Ménétriés, 1832) [7] and the Common Pochard Aythya ferina (Linnaeus, 1758) [8].

The Common Pochard is a Eurasian duck found in a wide variety of wetlands (marshes, lagoons, lakes, artificial reservoirs, and rivers), with eutrophic to $\mathrm{pH}$ neutral waters, but it mostly prefers large open bodies of water with abundant emergent vegetation [8-10]. In Morocco, it is a winter visitor, passage migrant, and occasional to regular breeder [4, 11, 12]. Evident nesting cases have been observed in five Northern marshlands: "Plan d'eau de Dwiyate" $[4,13]$, "Merja Bargha” [4, 14], "Marais de Smir" [15], "Merja de Sidi Bou Ghaba" (with the highest number of breeding pairs, nationally: 25 in 2011) [16], "Merja de Fouwarate" [17], and in two Atlas lakes ("Aguelmam Afennourir" and "Dayet 'Awa" [4]). The threats faced by the species and its limited breeding population have rendered it vulnerable in Morocco [16].

The Marbled Teal is commonly found in shallow brackish wetlands [18], with rich emergent and submerging vegetation $[9,19,20]$, avoiding open-water areas [20-22]. However, its distribution largely varies with seasons, especially depending on its dietary needs [18]. In Morocco, it is a resident breeder, winter visitor, and passage migrant $[4,11]$. Its breeding population was estimated to 50-250 pairs [23], distributed in a dozen wetlands situated in the north and south of the country $[4,16,17,23-25]$. Nevertheless, It regularly breeds in four wetlands $[16,17,24]$ : "Merja de Sidi Bou Ghaba," "Merja de Fouwarate," "Plan d'eau de Dwiyate," and "Embouchure de Wad Massa." The species is considered endangered in Morocco [16] mainly because of its habitat degradation and modification [16].

The White-headed Duck is the only Palearctic species of the Oxyurini tribe [26]. Breeding birds are usually found in freshwater and brackish or eutrophic lakes with dense emergent vegetation [22, 27], shallow and permanent or semipermanent [9], while wintering birds can be found in deeper and larger wetlands, alkaline or saline, and with less vegetation [28]. In Morocco, it is a winter visitor, resident breeder, and suspected passage migrant [11]. It used to breed in Morocco until the $20^{\text {th }}$ century, before becoming scarce and disappearing, due its habitats' loss by agricultural development and droughts [25]. Since the 1990s, the species reappeared in "Plan d'eau de Dwiyate" [4, 29] and then expanded progressively to several other breeding sites [30, 31]: "Merja de Sidi Bou Ghaba," "Merja de Fouwarate," "Barrage 'Arabat,", "Barrage El Mehraz," "Merja Bargha," cumulating about 60 couples. It is still vulnerable in Morocco [12].

\section{Methodology}

2.1. Counting Procedure. Our study is based on the dataset of the waterbirds' winter census, between 1983 and 2019. The counting procedure was adopted according to standard bird monitoring techniques [32], and the protocol was refined over the years $[14,33-35]$. The censuses are conducted annually, usually during January, to avoid recounts.
Nevertheless, given the large number of wetlands to be censused, some missions can start in late December (especially in the Saharan region). Moreover, in some rare cases, data from censuses during the $1^{\text {st }}$ week of February were accepted; they were conducted in some sites (Atlas lakes) that were not accessible, during January, because of heavy snow. The number of wetlands censused, at least once, in the context of this program is 272 (IWC wetlands network). However, not all of them are visited every year, depending on the availability of human, financial, and logistical resources. The priority is always given to the wetlands with the highest waterbirds' numbers and specific richness.

During each visit, the observers (Table S4) counted all waterbirds on the grounds, in the water, and even those flying inside the site, using binoculars and telescopes. Counting points and transects are determined for each wetland, depending on its configuration and accessibility. When some wetlands are close to one another, in a way that allows frequent bird exchange between them, they are considered as complex sites and are covered during the same visit. Over the years (especially since the 1990s), most wetlands have been censused by the same group of observers, using the same protocol; this makes the obtained data more homogenous, comparable, and reliable. The observers participating in the IWC program are ornithologists, qualified and trained for bird identification. New observers can join the program after going through training sessions on bird identification and counting methods, both theoretical and practical. During their learning phase, they can join the established observers' teams during their census campaigns to strengthen their training.

2.2. Data Analysis. The wintering waterbirds' numbers are entered in an information system, which generates automatically tables per species and sites.

To calculate populations' trends, we used the TRIM (TRends and Indices for Monitoring Data) freeware [36] (version 3.54). TRIM generates estimations for missing counts and can analyze data for 4000 sites, over 100 years; this makes it very suitable for our large dataset, especially since not all sites are visited every year (Table 1 ). The missing data imputations take into account a site effect and a time effect, assuming the counts in a year depend on those of the year before (serial correlation). The counts are assumed to be Poisson distributed and are converted into annual indices to simulate the missing data and calculate trends, based on the completed dataset (with the first year as base year, to which the index 1 is attributed. The overdispersion (when the variance is larger than expected for a Poisson distribution) and the serial correlation can be estimated by TRIM, through a generalized estimating equation (GEE) approach.

The recommended overall slope by TRIM is based on the imputed data and given with the results of the additive slope and the multiplicative slope, which reflects the magnitude of annual change, as well as their standard errors. It is converted into one of six trend categories: (i) strong increase: an increase significantly greater than $5 \%$ per year; (ii) moderate 
TABLE 1: Number and percentage of wetlands visited per year.

\begin{tabular}{|c|c|c|}
\hline Year & Number of surveyed wetlands & $\%$ of the IWC wetlands network (272) \\
\hline Average & 73 & 27 \\
\hline 1983 & 47 & 17 \\
\hline 1984 & 82 & 30 \\
\hline 1985 & 49 & 18 \\
\hline 1986 & 35 & 13 \\
\hline 1987 & 69 & 25 \\
\hline 1988 & 69 & 25 \\
\hline 1989 & 56 & 21 \\
\hline 1990 & 71 & 26 \\
\hline 1991 & 94 & 35 \\
\hline 1992 & 86 & 32 \\
\hline 1993 & 94 & 35 \\
\hline 1994 & 77 & 28 \\
\hline 1995 & 89 & 33 \\
\hline 1996 & 46 & 17 \\
\hline 1997 & 70 & 26 \\
\hline 1998 & 65 & 24 \\
\hline 1999 & 65 & 24 \\
\hline 2000 & 62 & 23 \\
\hline 2001 & 65 & 24 \\
\hline 2002 & 56 & 21 \\
\hline 2003 & 62 & 23 \\
\hline 2004 & 65 & 24 \\
\hline 2005 & 59 & 22 \\
\hline 2006 & 66 & 24 \\
\hline 2007 & 77 & 28 \\
\hline 2008 & 85 & 31 \\
\hline 2009 & 79 & 29 \\
\hline 2010 & 62 & 23 \\
\hline 2011 & 100 & 37 \\
\hline 2012 & 43 & 16 \\
\hline 2013 & 78 & 29 \\
\hline 2014 & 115 & 42 \\
\hline 2015 & 70 & 26 \\
\hline 2016 & 88 & 32 \\
\hline 2017 & 76 & 28 \\
\hline 2018 & 99 & 36 \\
\hline 2019 & 131 & 48 \\
\hline
\end{tabular}

increase: a significant increase, but not significantly more than 5\% per year; (iii) stable: no significant increase or decline, and it is certain that trends are less than 5\% per year; (iv) uncertain: no significant increase or decline, but not certain if trends are less than $5 \%$ per year; (v) moderate decline: significant decline, but not significantly more than $5 \%$ year; (vi) steep decline: decline significantly greater than $5 \%$ year. A significance threshold is also provided for the increasing and declining trends: (i) highly significant: $p<0.01$ (i.e., confidence level of 99\%); (ii) significant: $p<0.05$ (i.e., confidence level of $95 \%$ ).

For the Common Pochard and the Marbled Teal TRIM analyses, three periods were considered: long term (1983-2019), medium term (2000-2019), and short term (2010-2019). For the White-headed Duck, which has been regularly observed in Morocco only starting 2005, the trend was calculated for the periods of 2005-2019 (long term) and 2010-2019 (short term).
To better understand the species evolution, we used different parameters, mainly as follows:

(i) The average number of a species in each site is calculated for the long term and short term and corresponds to the arithmetic mean.

(ii) The national average corresponds to the sum of the average numbers in each site.

(iii) The total annual numbers correspond to the sum of the species numbers in each site for every year.

(iv) The total number per site is the sum of all the species numbers observed per year in said site.

(v) The occurrence of a species in a site corresponds to the number of winters it has been observed in this site.

(vi) The census number of a site corresponds to the number of years during which it has been visited. 
(vii) The occurrence percentage of a species in a site corresponds to the ratio of its occurrence to the site's census number.

(viii) The 1st census of a site corresponds to the first year during which it has been visited.

(ix) The standard deviation was calculated for each site, to determine the deviation of the numbers observed annually from the average.

$$
\sigma=\sqrt{\frac{\sum\left(x_{i}-\bar{x}\right)^{2}}{N}},
$$

where $x_{i}$ is the observed number in site $i, \bar{x}$ is the arithmetic mean, and $N$ is the number of observations.

To prioritize future conservation measures, we have identified for each species, categories of key sites, based on recent data (2010-2019):

(i) Sites of international importance, priority 1 (SII1): wetlands verifying the 6th Ramsar criterion (the species' numbers reach or exceed regularly (5 winters or more) $1 \%$ of its regional population.

(ii) Sites of international importance, priority 2 (SII2), verifying the 2 nd Ramsar criterion (sites supporting vulnerable, endangered, or critically endangered species).

(iii) Sites of national importance (SNI): the species' average number, in those sites, equals or exceeds the $1 \%$ of the national average.

(iv) Sites of potential national importance (SPNI): they hosted, during at least winter, more than $1 \%$ of the national average.

\section{Results}

3.1. Populations' Size and Trend. The national average of the Common Pochard's wintering population is 11.158 in the long term, the total annual numbers varying between 1.710 (in 2012) and 20.458 ducks (in 2002) (Figure 1). During the last decade (2010-2019), the national average is lower (7.496 individuals), but it represents $1.25 \%$ of the regional population "Central and NE Europe/Black Sea and Mediterranean" [37]. The Common Pochard was present in 809 counts and absent in 991 counts (no observed birds during visits), while 2.640 data are missing (the unavailable records relative to the species' known wintering sites, which have not been visited during certain years) (Table S1). Its population trend (Figure 1) is stable in the long term (additive slope $=-0.0101 \pm 0.0057$; multiplicative slope $=0.9900 \pm 0.0057)$, a significant moderate decline in the medium term (additive slope $=-0.0727 \pm 0.0117$; multiplicative slope $=0.9299 \pm 0.0109 ; p<0,01)$, and uncertain in the short term (additive slope $=-0.0226 \pm 0.0279$; multiplicative slope $=0.9776 \pm 0.0273$ ), but with a declining tendency. This decline is more evident during the last decade (2010-2019) even though the census effort has significantly increased.

The Marbled Teal's national average is almost the same, in the long term (3.071) and short term (3.070).
However, this number hides very high interannual fluctuations (Figure 2), knowing that the total annual numbers vary between 27 (in 1996) and 3.755 ducks (in 2013). Morocco hosts $47 \%$ of the regional population "West Mediterranean/West Mediterranean and West Africa" [37]. The species was present in 295 counts and absent in 651 counts (no observed birds during visits), while 904 data are missing (Table S2). Its population trend (Figure 2) is stable in the long term (additive slope $=-0.0050$ \pm 0.0092 ; multiplicative slope $=0.9950 \pm 0.0092$ ), whilst it is uncertain in the medium term (additive slope =$0.0208 \pm 0.00169 ;$ multiplicative slope $=0.9794 \pm 0.0166$ ) and short term (additive slope $=0.0097 \pm 0.0447$; multiplicative slope $=1.0097 \pm 0.0452)$.

The White-headed Duck's national average is 445 between 2005 and 2019 and 542 individuals during the last decade (2010-2019). Morocco hosts 22\% of the regional population "Spain and Morocco" [37]. The observed total annual numbers varied between 1 and 1.730 (Figure 3). The species was observed, in the context of IWC, during the period 2005-2019 and was present in 29 counts and absent in 58 counts (no observed birds during visits), while 45 records are missing (Table S3). The population's trend (Figure 3), for the 2005-2019 period, is a moderate increase (additive slope $=0.2749 \pm 0.1181$; multiplicative slope $=1.3164 \pm 0.1554 ; p<0,05)$. In the short term, it is uncertain (additive slope $=0.3899 \pm 0.4609$; multiplicative slope $=1.4768 \pm 0.6807)$, but with an increasing tendency.

3.2. Spatial Distribution. The Common Pochard was observed in a total of 118 wetlands (43\% of the surveyed wetlands) (Table S1), mostly in the Northern half of the country, along the Atlantic coast and Atlas region (Figure 4). However, from year to year, the species was reported in 9 to 39 sites (Figure 1). Between 2010 and 2019, the northwest (31 sites) and northeast (16 sites) regions hosted the highest concentrations (37\% and $33 \%$, respectively). Amongst the sites visited at least 19 winters over the 37 years study period, the species occurrence percentage was the highest in five of them (>85\%): "Aguelmam Abekhane," "Aguelmam Afennourir," "Merja de Sidi Bou Ghaba," "Dayet Ifrah" and "Barrage de Smir." The highest total numbers (between 1983 and 2019) were cumulated as follows: "Barrage Mohammed V," "Barrage Al Massira," and "Embouchure de Wad Massa." In the short term (amongst the sites visited at least 5 years out of 10), the highest average numbers were recorded in "Barrage Mohammed V" and "Merja de Sidi Bou Ghaba" (Table 2). Some wetlands have known a decline in the species' wintering numbers, such as "Embouchure de Wad Massa;" others such as "Merja de Fouwarate" have hosted increasing numbers in recent years. The highest concentration ever recorded in Morocco (15.600 birds) was observed in the reservoir of "Barrage Mohammed V" in 2002. This site has known high fluctuations of the Common Pochard's numbers (zero to thousands), which is clearly reflected by its high standard deviation (Table 2).

The Marbled Teal was observed in a total of 50 wetlands (18\% of the surveyed wetlands) (Table S2), mainly 


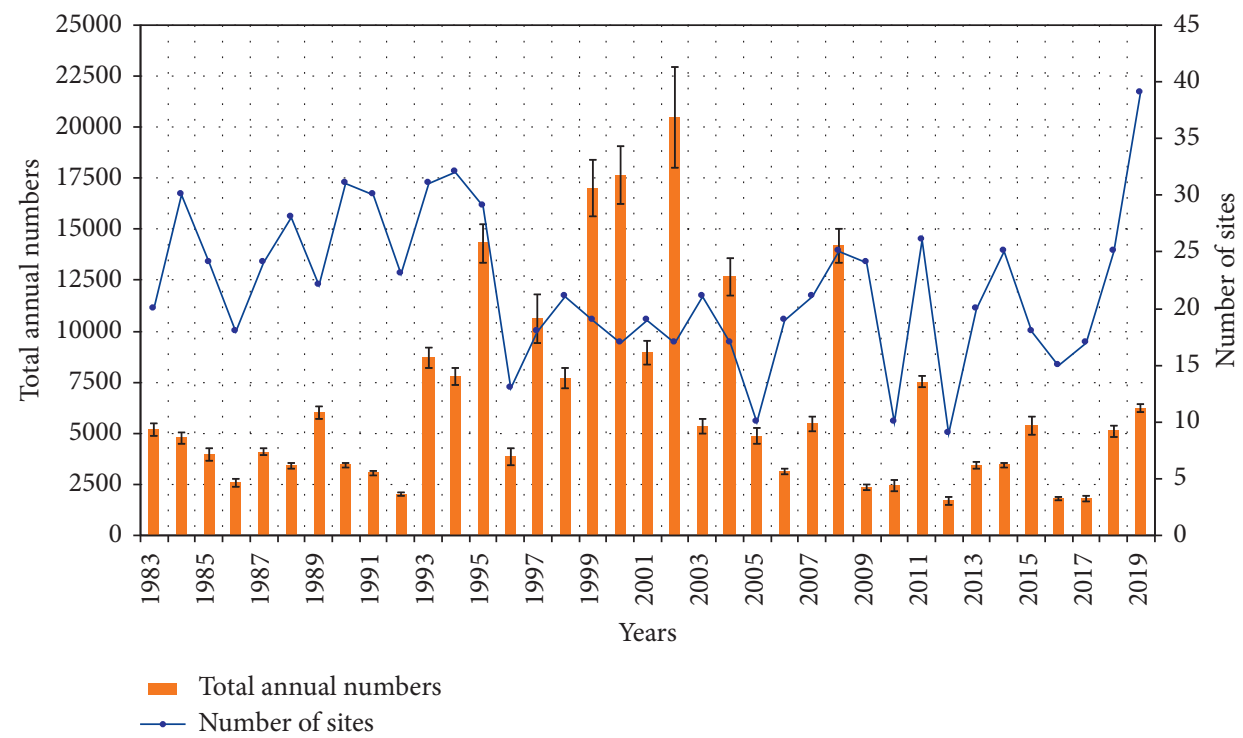

(a)

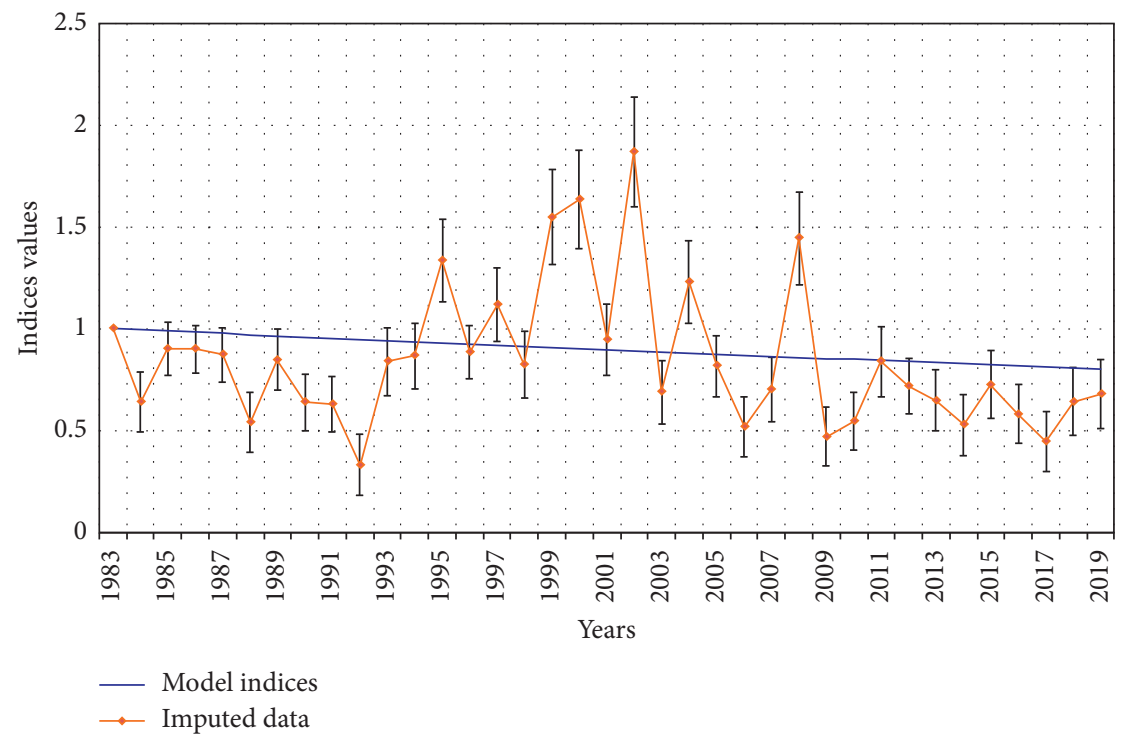

(b)

Figure 1: (a) Total annual numbers of the Common Pochard and number of wetlands where it has been observed in Morocco between 1983 and 2019. (b) Linear trend of the wintering population (TRIM analysis).

distributed north and west to the Atlas Mountains and in the northern part of the Sahara (Figure 5). Annual distribution varied between 2 and 19 sites (Figure 2). In the short term, $67 \%$ of the national average was observed in the southern region (in 15 wetlands), with particularly high concentrations in 2013 (95\%) and 2018 (62\%). The other regions hosted $8 \%$ to $15 \%$ of this number. The highest occurrence of the species was recorded in "Merja de Sidi Bou Ghaba" (97\% of the visits), "Lagunes de Sidi Moussa-Walidia" (83\%), and "Embouchure de Wad Massa" (81\%). Three sites hosted each, more than $10 \%$ of the total numbers recorded between 1983 and 2019: "Lagunes de Sidi Moussa-Walidia," "Wad As-Saqia Al Hamra à La'youn," and "Merja de Sidi Bou Ghaba." The highest standard deviations were recorded in two sites (Table 3 ): (i) "STEU Guelmim": a wastewater treatment plant, only visited in 2016 ( 89 ducks) and in 2018 during which a high concentration of 1.748 was recorded.

(ii) "Was As-Saqia Al Hamra à La'youn": observations varied between 0 individuals and the highest concentration ever recorded in Moroccan sites (3.557, almost half of the national population in 2013).

Since its reappearance in Morocco in the early 2000s, the White-headed Duck was observed in 12 wetlands (17\% of the surveyed wetlands), mainly in the north of the country (Table S3; Figures 3 and 6). Its annual distribution did not exceed six sites, and it was not observed in any wetland visited in 2006, 2007, 2010, and 2012 (Figure 3). Most of its population is located in the northwest region $(73 \%)$. The 


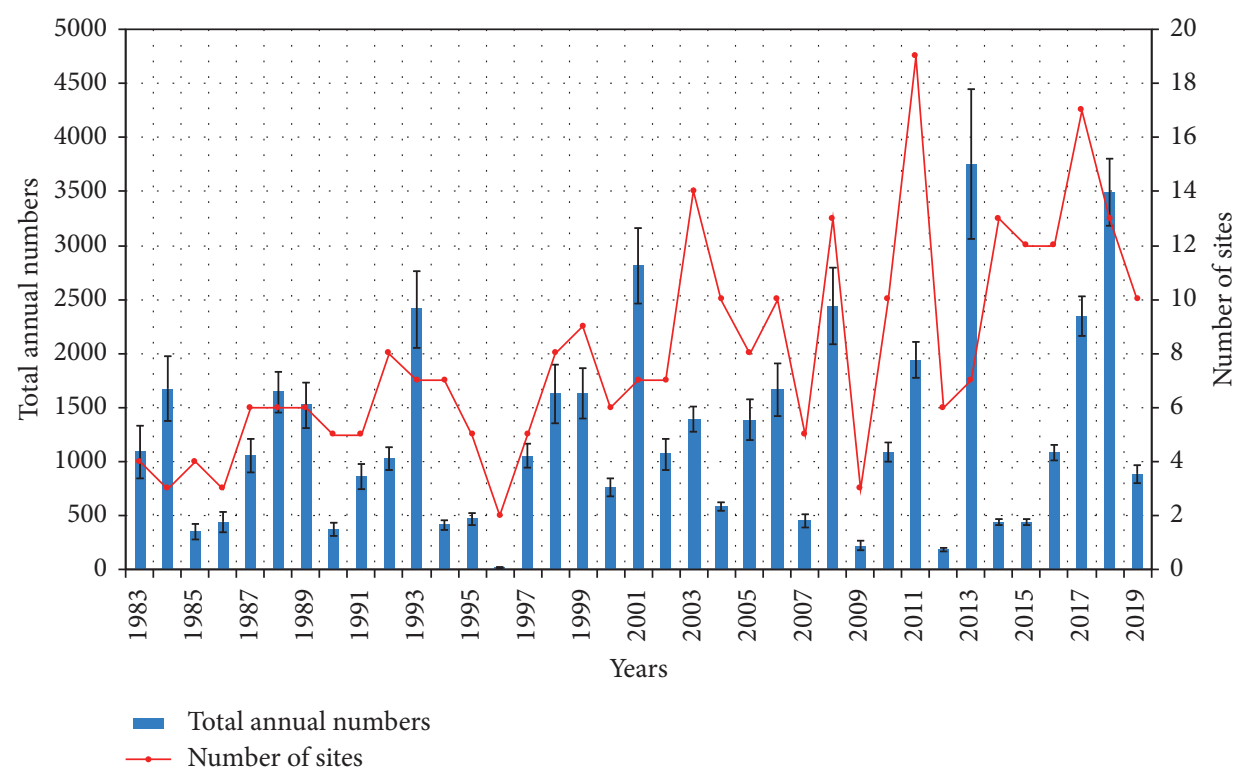

(a)

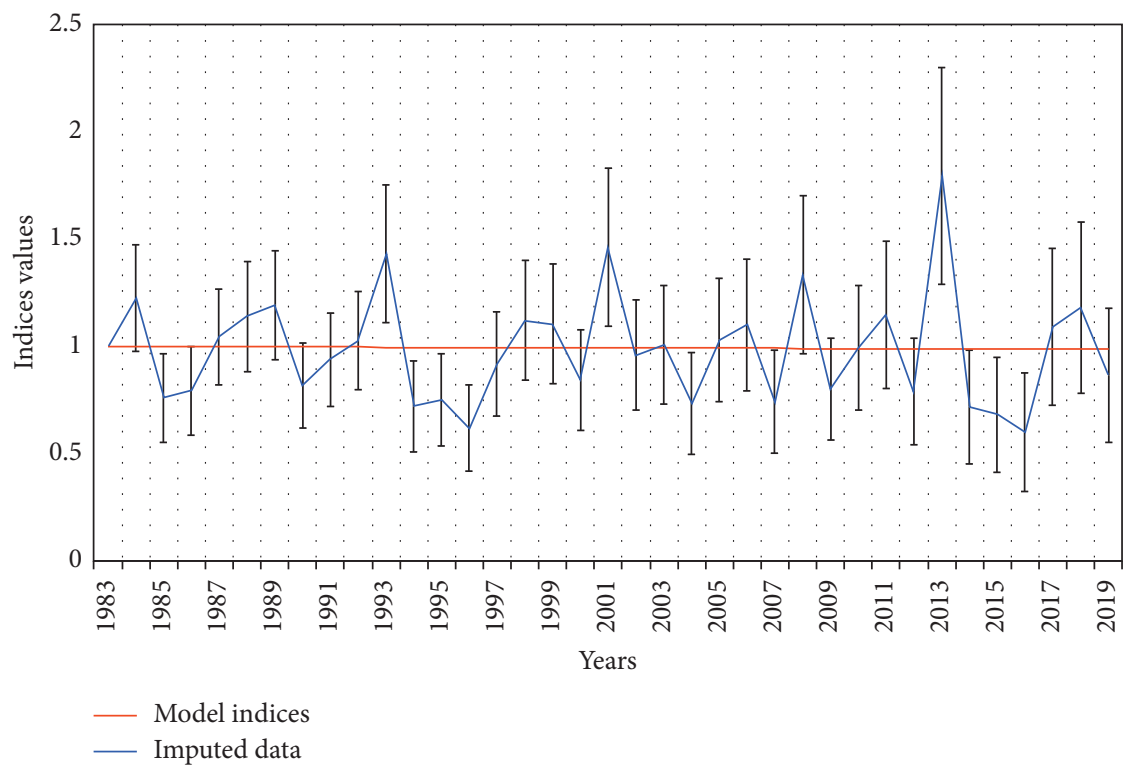

(b)

Figure 2: (a) Total annual numbers of the Marbled Teal and the number of wetlands where it has been observed in Morocco between 1983 and 2019. (b) Linear trend of the wintering population (TRIM analysis).

species was most regular in "Merja de Sidi Bou Ghaba" (75\% of the visits) and "Merja de Fouwarate" (45\%). Three wetlands ("Merja de Fouwarate," "Merja de Sidi Bou Ghaba," and "Barrage Mohammed V") hosted more than $10 \%$ of the wintering individuals. It is worth mentioning that the wetland "Plan d'eau de Dwiyate" is hard to access, since it is part of a royal domain. Except for a temporary lake on the east (suffering from some disturbance, overgrazing, and recurrent droughts [29]), it is fenced and well-guarded and hence with no disturbance, which makes it a site of great importance for the species. The highest standard deviation was recorded in "Merja de Fouwarate" (Table 4), where the species was not observed before 2014 (Table S3) and where the highest concentrations nationally were recorded (1.430 in 2018 and 500 in 2019).

3.3. Sites of International and National Importance. The Common Pochard is a globally vulnerable species, which makes all the sites hosting it of international importance (SII2 as we have defined in Methodology). None of the Moroccan wetlands verify the Ramsar criterion 6 for the species. Nevertheless, it is worth mentioning that "Barrage Mohammed V" could be of potential international importance. In fact, in 2002, this site hosted a high concentration of 15.600 ducks, which exceeded the estimated $1 \%$ of the 


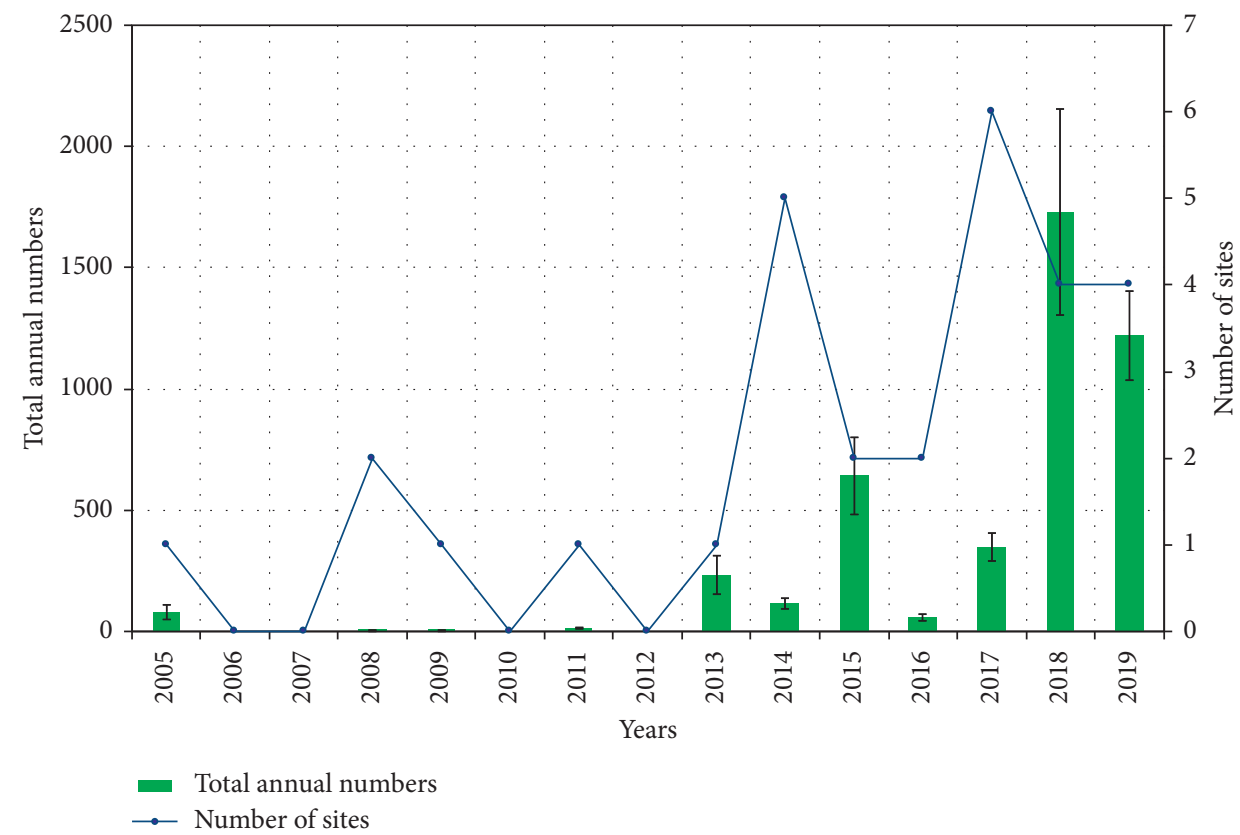

(a)

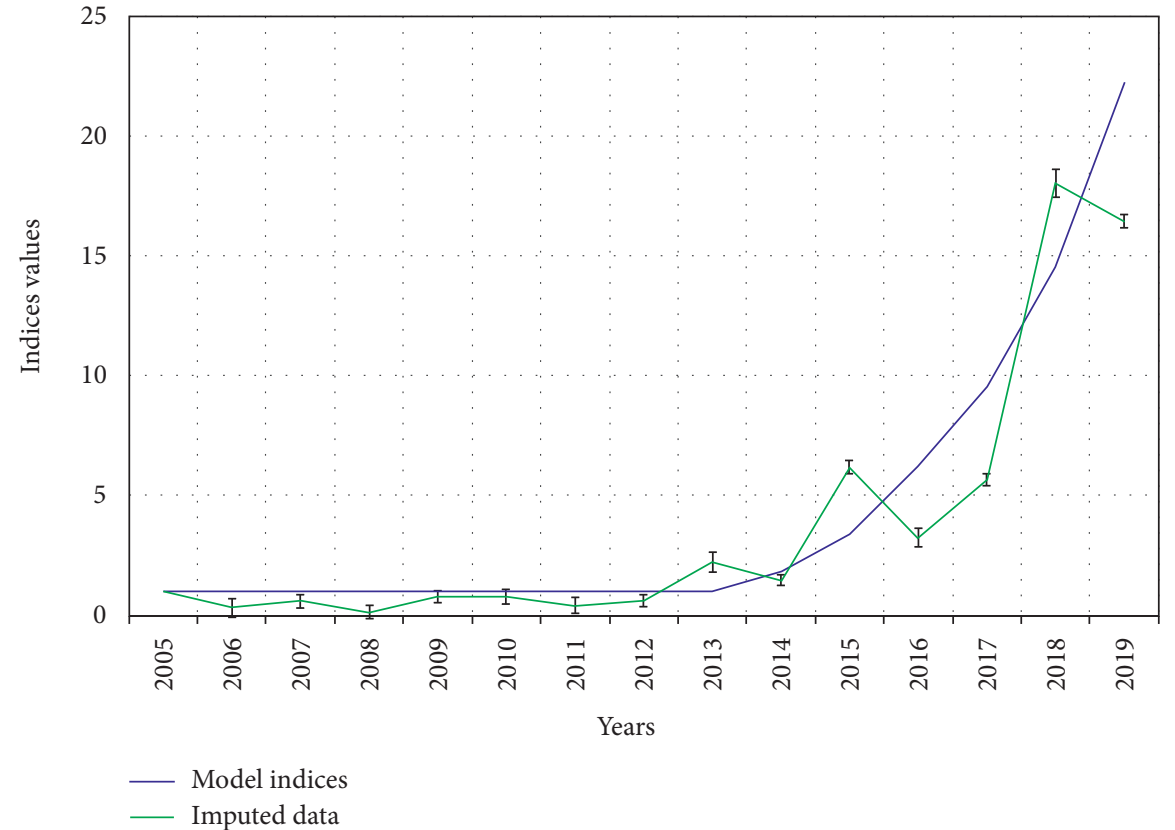

(b)

FIgURE 3: (a) Total annual numbers of the White-headed Duck and the number of wetlands where it has been observed in Morocco between 2005 and 2019. (b) Linear trend of the wintering population (TRIM analysis).

regional population at the time (10.000) [37]. The reported species' numbers in this wetland can be highly underestimated due to a difficult access to many parts of the reservoir, depending on the conditions. Therefore, it can, more than likely, host regularly at least $1 \%$ of the Common Pochard's regional population. This could also be the case for "Barrage Al Massira," a reservoir often partially censused and which hosted, in 2008, 5.500 ducks. Among the 118 wetlands where the species was observed, 26 have average numbers equal or superior to $1 \%$ the national average
(7.496) (Table 2), which makes them of national importance. On the contrary, 15 others hosted wintering numbers exceeding that threshold, during at least one winter (Table 2), which makes them of potential national importance.

The Marbled Teal is a globally vulnerable species, which makes all the sites hosting it of international importance as well (SII2). Moreover, 18 wetlands hosted, at least once, more than $1 \%$ of the regional population [5], three of them regularly: "Lagunes de Sidi Moussa-Walidia," "Merja Zerga," and "Wad As-Saqia Al Hamra à La'youn;" they are thus of international 


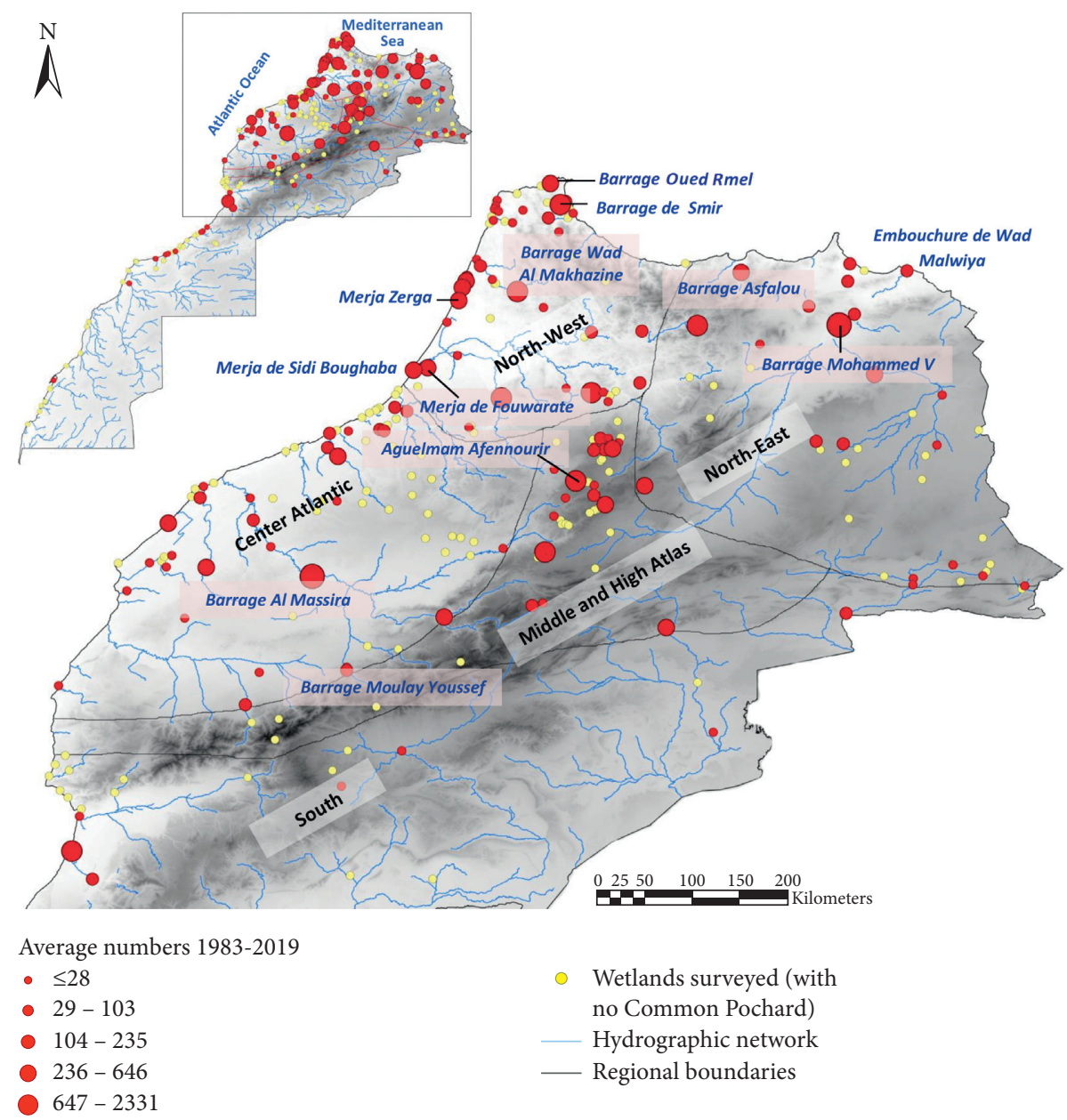

FIgURe 4: Distribution map of the Common Pochard's wintering population in Morocco (1983-2019).

importance for the species (SII1) (Table 3). On the contrary, 26 wetlands have average numbers equal or superior to $1 \%$ of the national average (Table 3), which makes them of national importance. Among them, 11 hosted wintering numbers exceeding that threshold during at least one winter (Table 3), which makes them of potential national importance.

Because it is endangered, the White-headed Duck attributes an international importance to all the 12 sites hosting it (SII2). The $1 \%$ of the regional population [37] was exceeded, at least one winter, in five wetlands, but regularly in "Merja de Sidi Bou Ghaba" and "Merja de Fouwarate." On the contrary, seven wetlands hosted, at least once, more than $1 \%$ of the national average, cumulating $99.8 \%$ of this number. Among them, 6 are of national importance and one is of the potential national importance (Table 4).

For the three species, some sites need to be monitored more regularly to verify and/or confirm their national/international importance since they have been visited less than 5 winters (Tables S1-S3).

3.4. Current Conservation Measures in Morocco towards the Three Species. An efficient legal conservation way consists in classifying a bird in an official list of protected species. Two main lists exist in the Moroccan legislation: a list of species for which hunting is banned (published through the "Annual Hunting Order") and a list of species in which trade and transport is conditioned by a special governmental authorization (through the CITES Law " $\mathrm{N}^{\circ} 29-5$ "). The hunting of the White-headed Duck and Marbled Teal is prohibited in Morocco, whilst the Common Pochard can still be hunted [38].

National action plans for species can also be efficient tools for the conservation of birds and their habitats. In Morocco, only the White-headed Duck has a national action plan [18].

In situ conservation mechanisms represent another important measure for the conservation of the three species. In addition to two international statuses for the conservation of wetlands: (i) Ramsar Sites and Important Bird and Biodiversity Areas (IBA), these mechanisms also consist, in Morocco, in the creation of three national statuses for which a high number of wetlands have been designated for. Several bird species, including the three ducks subject of this article, have been targeted by these statuses: (i) national parks (NPs); (ii) Sites of Biological and Ecological Interest (SBEI), defined in 1996 [39], with at least 84 wetlands, partly assessed using waterbirds; and (iii) permanent hunting reserves (PHRs).

The Common Pochard is found in 44 wetlands, with at least one conservation status (Table 5); 22 of them are Ramsar sites, 
TABle 2: Most important wintering sites of the Common Pochard (2010-2019).

\begin{tabular}{|c|c|c|c|c|c|}
\hline Site name & Average number ${ }^{1}$ & $\operatorname{Max.}^{2}$ & $\begin{array}{c}1 \% \\
\mathrm{NA}^{3} \\
\end{array}$ & Importance & Standard deviation \\
\hline Barrage Hassan Ad-Dakhil & 850 & 1700 & 1 & SNI/SII2 & 530 \\
\hline Barrage Mohammed V & 626 & 15600 & 2 & SNI/SII2 & 3816 \\
\hline Merja de Sidi Bou Ghaba & 514 & 1200 & 8 & SNI/SII2 & 258 \\
\hline Aguelmam Afennourir & 468 & 2600 & 4 & SNI/SII2 & 624 \\
\hline Merja de Wad Fouwarate & 413 & 1000 & 8 & SNI/SII2 & 308 \\
\hline Barrage Wad Al Makhazine & 317 & 1101 & 3 & SNI/SII2 & 345 \\
\hline Barrage de Smir & 312 & 1689 & 4 & SNI/SII2 & 462 \\
\hline Sadd Al Ajras & 305 & 305 & 1 & SNI/SII2 & 98 \\
\hline Barrage Asfalou & 300 & 300 & 1 & SNI/SII2 & 0 \\
\hline Aguelmam Abekhane & 296 & 855 & 2 & SNI/SII2 & 200 \\
\hline Barrage Al Massira & 256 & 7038 & 3 & SNI/SII2 & 1853 \\
\hline Aguelmam N'Tifounassine & 227 & 652 & 1 & SNI/SII2 & 145 \\
\hline Merja Zerga & 210 & 1800 & 2 & SNI/SII2 & 324 \\
\hline Barrage Hassan II & 186 & 1100 & 2 & SNI/SII2 & 327 \\
\hline Dayet Ifrah & 180 & 860 & 3 & SNI/SII2 & 218 \\
\hline Aguelmams Sidi Ali-Ta'nzoult & 172 & 1700 & 4 & SNI/SII2 & 360 \\
\hline Barrage Mechra' Hommadi & 126 & 290 & 2 & SNI/SII2 & 82 \\
\hline Barrage Enjil & 124 & 690 & 3 & SNI/SII2 & 179 \\
\hline Barrage Oued Rmel & 124 & 160 & 2 & SNI/SII2 & 37 \\
\hline Dayet 'Awa & 122 & 1030 & 3 & SNI/SII2 & 192 \\
\hline Embouchure de Wad Malwiya & 104 & 224 & 5 & SNI/SII2 & 67 \\
\hline Barrage Moulay Youssef & 94 & 114 & 1 & SNI/SII2 & 43 \\
\hline Merja Bargha & 89 & 1590 & 4 & SNI/SII2 & 323 \\
\hline Marais de Wad Smir & 87 & 391 & 3 & SNI/SII2 & 83 \\
\hline Barrage Sahla & 85 & 164 & 1 & SNI/SII2 & 80 \\
\hline Barrage Al Wahda & 84 & 283 & 1 & SNI/SII2 & 117 \\
\hline Barrage Hassar & 74 & 148 & 3 & SPNI/SII2 & 60 \\
\hline Mlalah du Bas Tahaddart & 69 & 480 & 1 & SPNI/SII2 & 96 \\
\hline Barrage Kheng El Hda & 67 & 200 & 4 & SPNI/SII2 & 61 \\
\hline Barrage Petit Tizil & 52 & 250 & 2 & SPNI/SII2 & 79 \\
\hline Dayet Hachlaf & 45 & 163 & 1 & SPNI/SII2 & 56 \\
\hline Barrage Zelmou & 38 & 159 & 1 & SPNI/SII2 & 44 \\
\hline Barrage'Arabat & 38 & 94 & 1 & SPNI/SII2 & 40 \\
\hline Barrage Idriss Premier & 34 & 570 & 1 & SPNI/SII2 & 156 \\
\hline Marais du bas Loukkos & 34 & 410 & 1 & SPNI/SII2 & 83 \\
\hline Merja des Wlad Khallouf & 30 & 240 & 1 & SPNI/SII2 & 53 \\
\hline Merja Al Halloufa & 25 & 680 & 2 & SPNI/SII2 & 220 \\
\hline Embouchure de Wad Massa & 23 & 3330 & 1 & SPNI/SII2 & 832 \\
\hline Merja des Wlad Skher & 23 & 650 & 2 & SPNI/SII2 & 143 \\
\hline Lagunes de Sidi Moussa-Walidia & 16 & 2500 & 1 & SPNI/SII2 & 431 \\
\hline Sebkha Bou Areg & 12 & 406 & 1 & SPNI/SII2 & 109 \\
\hline
\end{tabular}

${ }^{1}$ The average (mean) of the species' annual numbers counted in a site (their sum is divided by the number of years the site was censused). ${ }^{2}$ Maximum wintering number observed in a site since its first year of census. ${ }^{3}$ Number of winters during which $1 \%$ of the national average $(7.496)$ is exceeded.

34 are SBEI, 21 are IBA, 9 are part of national parks, and 18 are part of permanent hunting reserves. The Marbled Teal occupies 25 wetlands having national and/or international conservation statuses: 15 Ramsar sites, 20 SBEI, 16 IBAs, 3 are part of national parks, and 10 are part of permanent hunting reserves. Among the 9 wintering wetlands of the White-headed Duck with conservation statuses, 6 are Ramsar sites, 7 SBEI, 5 IBA, 3 are part of national parks, and 5 are part of permanent hunting reserves.

\section{Discussion}

4.1. Population Size and Trend. The global population of the Common Pochard is considered to be decreasing [8]. Even though regional populations' trends differ from stable to unknown [8], the European population, which represents $35 \%$ to $40 \%$ of the global population, has decreased by $30-49 \%$ over three generations $[8,40,41]$.

The Moroccan wintering numbers show a significant decline, especially during the two recent decades, which could be directly linked to the declining trend of the regional population "Central and NE Europe/Black Sea and Mediterranean" [37, 42-44], from which the wintering individuals in Morocco originate. In fact, according to the IUCN [37], the species' decrease is mainly due to the loss of its breeding habitat in Eastern Europe. In Central Europe, it appears that the major factors responsible for its decline are nest predation $[37,45]$ by natural (Vulpes vulpes and Sus 


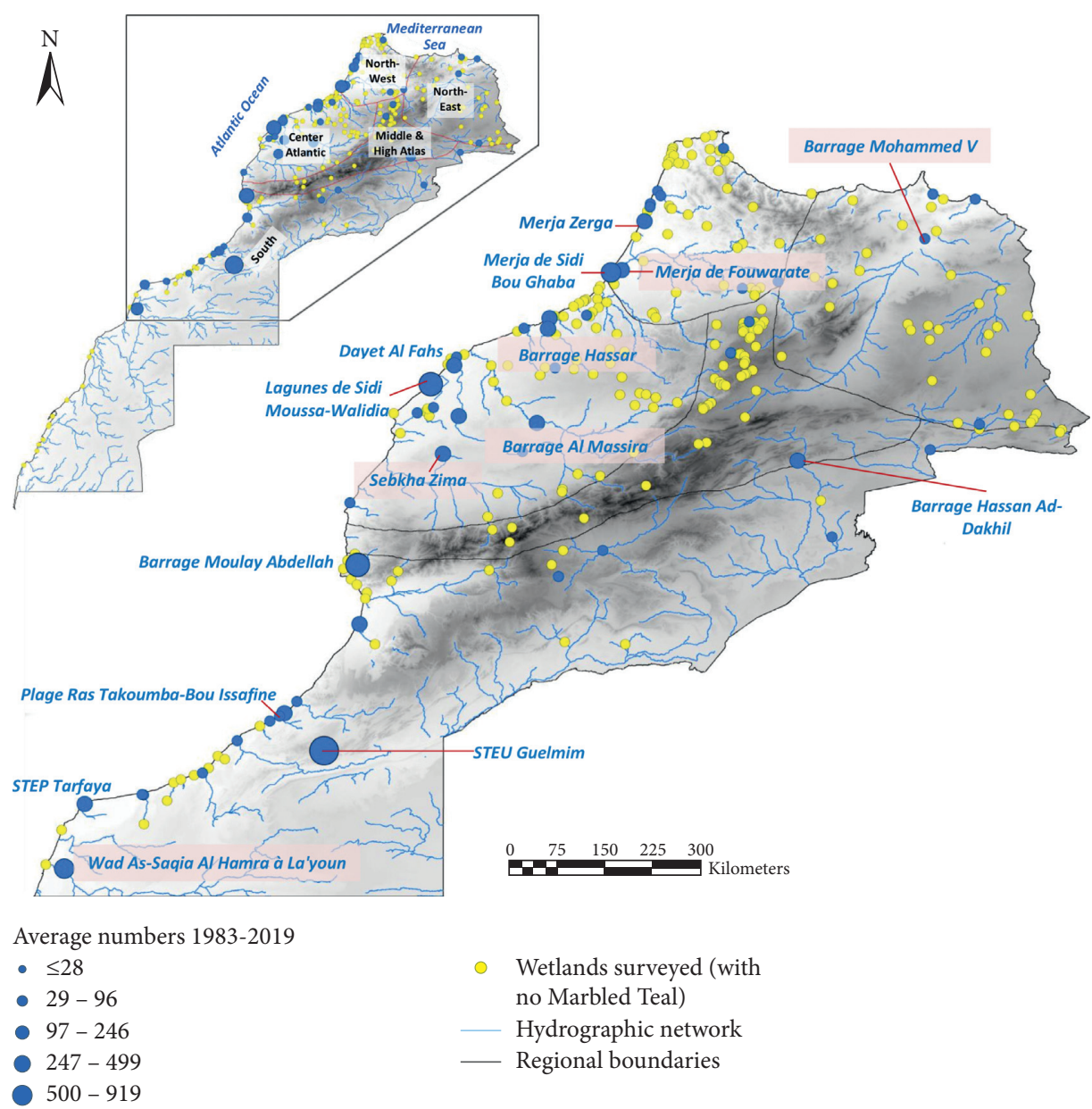

FIgURE 5: Distribution map of the Marbled Teal's wintering population in Morocco (1983-2019).

scrofa) and alien mammal species (i.e., Neovison vison, Nyctereutes procyonoides, and Procyon lotor) and a decline of Dreissena polymorpha, the zebra mussel which is the preferred food of this duck [46-48]. Furthermore, Fox et al. (2016) [41] have summarized multiple factors influencing the breeding population in the old continent; they are mostly related to loss or changes in habitats, food availability, predation, alien species, hunting $[9,49,50]$, fishing, disturbance, and lead poisoning [51]. On the contrary, Folliot et al. (2018) [52] suggest that decreasing wintering numbers in Western Europe can also be due to the decline of the breeding population in the southwest Asian flyway (especially in Siberia). In fact, analyses of ringing recoveries data showed that large wintering numbers in the northwest European flyway originate from the southwest Asian flyway, which brings to evidence the interactions and exchange between the different regional populations beyond the determined limits of the flyways. In addition to the aforementioned factors that are possibly contributing to the decline of the Common Pochard in Morocco, climate change can also play a crucial role in the species' populations changes [53-58] at a larger scale, as well as the direct threats faced by the species in Moroccan wetlands.

The evolution of the Marbled Teal's wintering population in Morocco is consistent with the trend of the regional population (West Mediterranean/West Mediterranean and West Africa), which is stable [42], but with a possible declining tendency [37]. The global population of the species has decreased rapidly overtime [7]; only the southwest Asian population knows a possible increase [37], albeit it may be due to an improvement in census coverage instead of actual changes within the population [7].

In Morocco, the Marbled Teal's population often showed a lot of fluctuations from one year to another. In fact, the species can have extreme fluctuations in its population's size depending on rainfall's annual variation [18]. It can therefore relocate to other areas that may be unmonitored and vice versa and hence giving the impression of an increase or decrease in numbers. This relocation could occur between wetlands of the same country as well as at a larger scale, between wintering areas of different countries. Moroccan wintering individuals can come from breeding sites in Europe (e.g., Spain) and North Africa [59] (especially Algeria, which hosts important numbers of the species [60-62]). Nevertheless, the high records observed sometimes are not necessarily caused by an influx from Spain but could be explained by the presence of unknown breeding sites of great importance in the country or in North Africa [59]. The sometimes declining numbers of the species in Morocco and other regions can also be function of the habitats' quality and availability. In fact, the global population's decrease was a 
TABLe 3: Most important wintering sites of the Marbled Teal (2010-2019).

\begin{tabular}{|c|c|c|c|c|c|}
\hline Site name & Average number ${ }^{1}$ & Max. $^{2}$ & $\begin{array}{c}1 \% \\
\mathrm{NA}^{3}\end{array}$ & Importance & Standard deviation \\
\hline Wad As-Saqia Al Hamra à La'youn & 448 & 3557 & 9 & SII1/SNI & 708 \\
\hline Lagunes de Sidi Moussa-Walidia & 157 & 1800 & 6 & SII1/SNI & 471 \\
\hline Merja Zerga & 83 & 200 & 9 & SII1/SNI & 49 \\
\hline STEU Guelmim & 919 & 1748 & 2 & SII2/SNI & 830 \\
\hline Barrage Moulay Abdellah & 499 & 997 & 1 & SII2/SNI & 499 \\
\hline Barrage Hassan Ad-Dakhil & 188 & 339 & 2 & SII2/SNI & 106 \\
\hline Sebkha Zima & 148 & 950 & 3 & SII2/SNI & 185 \\
\hline Merja de Fouwarate & 119 & 400 & 7 & SII2/SNI & 107 \\
\hline Merja de Sidi Bou Ghaba & 74 & 1400 & 3 & SII2/SNI & 302 \\
\hline Barrage Mohammed V & 50 & 230 & 2 & SII2/SNI & 49 \\
\hline STEP Tarfaya & 44 & 44 & 1 & SII2/SNI & 0 \\
\hline Dayet Al Fahs & 44 & 636 & 2 & SII2/SNI & 125 \\
\hline Radier de l'Oued Assaka & 43 & 75 & 2 & SII2/SNI & 32 \\
\hline Barrage Al Massira & 36 & 1973 & 3 & SII2/SNI & 355 \\
\hline Barrage Hassar & 36 & 128 & 2 & SII2/SNI & 48 \\
\hline Plage Ras Takoumba-Bou Issafine & 31 & 550 & 1 & SII2/SPNI & 161 \\
\hline Marais de Wad Al Maleh & 22 & 248 & 1 & SII2/SPNI & 86 \\
\hline Embouchure de Wad Massa & 20 & 397 & 3 & SII2/SPNI & 101 \\
\hline Plage Blanche & 17 & 136 & 1 & SII2/SPNI & 32 \\
\hline Embouchure de Wad Malwiya & 15 & 142 & 1 & SII2/SPNI & 27 \\
\hline Embouchure de Wad Bou Issafine & 13 & 60 & 1 & SII2/SPNI & 16 \\
\hline Embouchure de Wad Assaka & 13 & 52 & 1 & SII2/SPNI & 15 \\
\hline Marais du bas Loukkos & 11 & 82 & 2 & SII2/SPNI & 18 \\
\hline Dayet Taras El Ghoul & 8 & 350 & 1 & SII2/SPNI & 76 \\
\hline Daya Al Beyda & 6 & 37 & 1 & SII2/SPNI & 9 \\
\hline Barrage Zelmou & 5 & 37 & 1 & SII2/SPNI & 11 \\
\hline
\end{tabular}

${ }^{1}$ The average (mean) of the species' annual numbers counted in a site (their sum is divided by the number of years the site was censused). ${ }^{2}$ Maximum wintering number observed in a site since its first year of census. ${ }^{3}$ Number of winters during which $1 \%$ of the national average (3.070) is exceeded.

direct consequence of habitats' loss and degradation $[7,59,63]$ due mainly to drainage of wetlands for agricultural purposes and hydrological work [7]. In our country, for example, one of the most important breeding sites, the Iriki Lake (where the Marbled Teal used to breed in high numbers (hundreds of couples in the 1960s)), has disappeared because of the construction of a dam (Barrage Al Mansour Ad-Dahbi) [24]. Although this vulnerable duck is legally protected in Morocco [24], it still faces many threats affecting negatively its population. These threats are mainly related to human activities, disturbing, degrading, or destructing its habitats, and changes in water levels (caused by low precipitations, drainage, and hydraulic work). In fact, the species' wetlands occupancy in our country, especially in the breeding season, is closely dependent on habitat-related factors, such as the number and diversity of emergent vegetation species $[22,64,65]$, which are more predominant in Ramsar sites close to the coastline [65].

Since its return in Morocco, the White-headed Duck's population has known a moderate increase. Notwithstanding, the global population of the species is thought to be decreasing [6]. This decline is estimated to be $50-79 \%$ in three generations [6] even though many subpopulations are not thoroughly recorded, which may lead to an underestimation of the species counts $[6,66]$. The increase in this endangered duck's population in Morocco, especially the high numbers recorded in "Merja of Fouwarate" during the 2018 winter (1.430 individuals) [30], could have different potential explanations and combined factors:

(i) A flow of migrants from Spain: the conservation and protection efforts undertaken by Spain, over more than 30 years [29], have had a strong positive effect on the White-headed Duck's population in Spain and may have contributed to its return to Morocco and its increasing numbers in the country [29].

(ii) A flow of individuals from the regional population of "Algeria and Tunisia," which hosts significant breeding numbers of the White-headed Duck [66]. There are, currently, insufficient data to decide if there is any exchange between the West Mediterranean and North African subpopulations [66] that could also contribute to the species increase in Morocco. Nevertheless, our country is at an advantageous position between the increasing Spanish population and the Algerian one, which hosts high numbers of the species during the breeding season and throughout the year [66-70], but faces many threats in the country, especially illegal killing [71].

(iii) The decline in the population of the ruddy duck and its hybrids due to campaigns for its eradication in Spain, Europe [29, 72], and Morocco [73].

(iv) The presence of favorable breeding sites in Morocco, thanks to wetlands conservation efforts and 


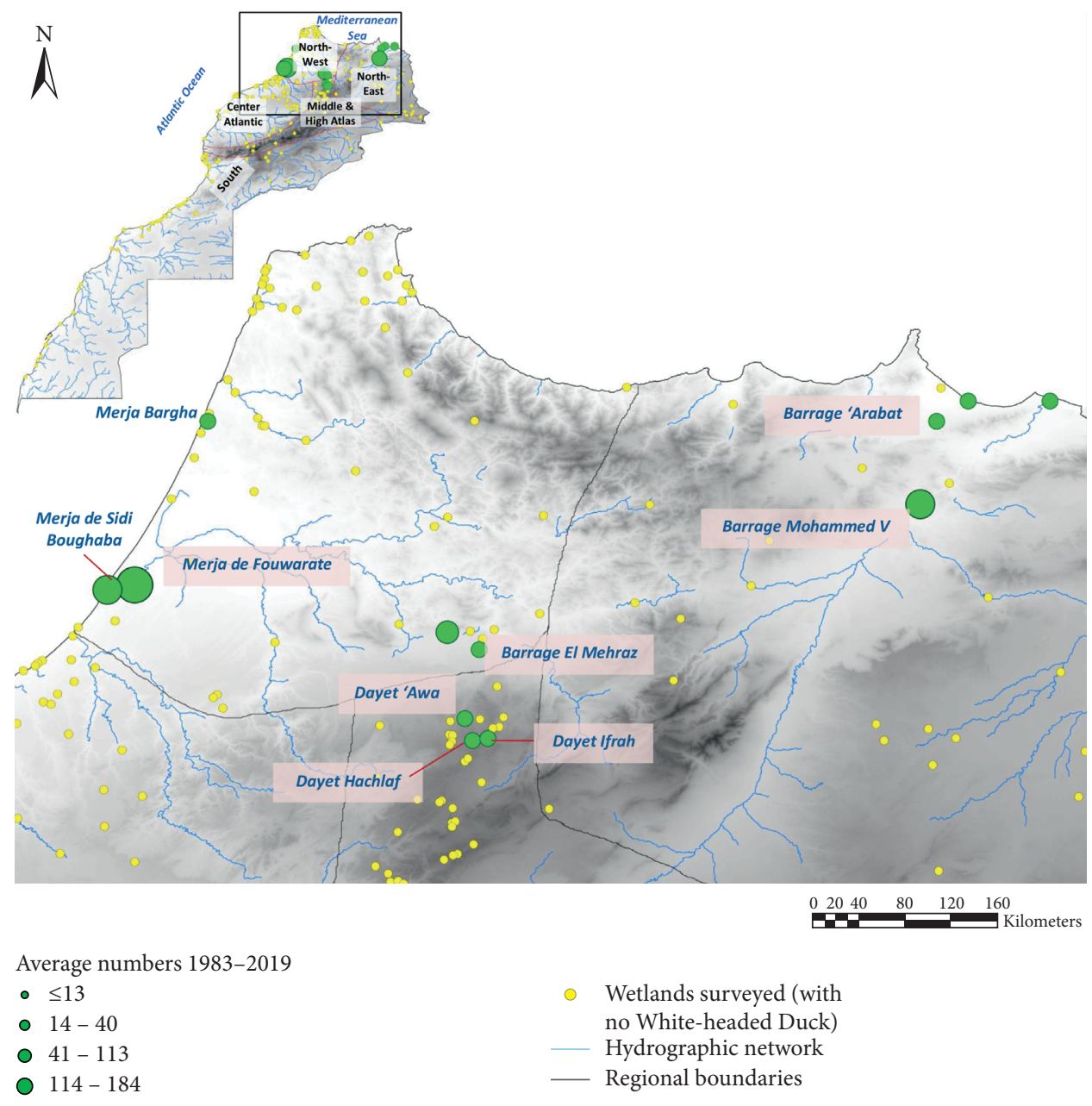

Figure 6: Distribution map of the White-headed Duck's wintering population in Morocco (2005-2019).

TABle 4: Most important wintering sites of the White-headed Duck (2010-2019).

\begin{tabular}{|c|c|c|c|c|c|}
\hline Site name & Average number ${ }^{1}$ & $\begin{array}{c}1 \% \\
\mathrm{NA}^{2} \\
\end{array}$ & Max. $^{3}$ & Importance & Standard deviation \\
\hline Merja de Sidi Bou Ghaba & 170 & 8 & 351 & SII1/SNI & 120 \\
\hline Merja de Wad Fouwarate & 225 & 5 & 1430 & SII2/SNI & 419 \\
\hline Barrage Mohammed V & 106 & 3 & 426 & SII2/SNI & 145 \\
\hline Dayet Ifrah & 15 & 2 & 59 & SII2/SNI & 19 \\
\hline Dayet Hachlaf & 15 & 1 & 88 & SII2/SNI & 31 \\
\hline Barrage'Arabat & 9 & 2 & 22 & SII2/SNI & 9 \\
\hline Barrage El Mehraz & 2 & 1 & 6 & SII2/SPNI & 3 \\
\hline Dayet'Awa & 1 & 0 & 3 & SII2 & 1 \\
\hline
\end{tabular}

${ }^{1}$ The average of the species' annual numbers counted in a site (their sum is divided by the number of years during which the site was censused). ${ }^{2}$ Maximum wintering number observed in a site since its first year of census. ${ }^{3}$ Number of winters during which $1 \%$ of the national average (542) is exceeded.

suitable climate conditions that contribute to good water levels [74] and more developed vegetation cover.

In Morocco, many factors have contributed to the former disappearance of this endangered duck and halted its expansion. Overgrazing and repeated cutting of reed beds caused a regression of emergent vegetation in permanent wetlands [29], which is crucial for this duck's breeding. According to El Hamoumi et al. [31], the species still faces many other threats; the most imminent one is the hybridization with the ruddy duck. In fact, this introduced species has been observed in Morocco on many occasions, and the last documented observation was in 2013, where 2 individuals were observed in Merja Al Halloufa [75]. Nevertheless, unpublished data (Hassani H. and Dakki M. in litt.) have reported the ruddy duck, during recent years in Barrage Al Mehraz in 2014 and 2015, one of the sites where breeding White-headed Ducks have been observed [31]. The second most imminent threat to the survival of the species in 
TABLE 5: Conservation statuses of the three species' hosting wetlands.

\begin{tabular}{|c|c|c|c|c|c|c|c|c|c|c|}
\hline Site name & Types of habitat & Region & Ramsar & $\mathrm{IBA}^{1}$ & $\mathrm{SBEI}^{2}$ & $\mathrm{NP}^{3}$ & $\mathrm{PHR}^{4}$ & Aytfer $^{5}$ & Marang $^{6}$ & Oxyleu $^{7}$ \\
\hline Aguelmam Abekhane & Inland lake & Atlas & - & - & $\mathrm{X}$ & - & - & $\mathrm{X}$ & - & - \\
\hline Aguelmam Afennourir & Inland lake & Atlas & $\mathrm{X}$ & - & $\mathrm{X}$ & $\mathrm{I}^{12}$ & $\mathrm{X}$ & $\mathrm{X}$ & $\mathrm{X}$ & - \\
\hline Aguelmam Azegza & Inland lake & Atlas & - & - & $\mathrm{X}$ & - & - & $\mathrm{X}$ & - & - \\
\hline Aguelmam N'Tifounassine & Inland lake & Atlas & $\mathrm{X}$ & $\mathrm{X}$ & $\mathrm{X}$ & $\mathrm{I}^{12}$ & $\mathrm{X}$ & $\mathrm{X}$ & - & - \\
\hline Aguelmam Wiwane & Inland lake & Atlas & - & - & $\mathrm{X}$ & - & - & $\mathrm{X}$ & - & - \\
\hline Aguelmams Sidi Ali-Ta'nzoult & Inland lake & Atlas & - & $\mathrm{X}$ & $\mathrm{X}$ & - & - & $\mathrm{X}$ & - & - \\
\hline Baie d'Ad-Dakhla ${ }^{(a)}$ & Bay & South & $\mathrm{X}$ & $\mathrm{X}$ & $\mathrm{X}$ & $\mathrm{D}^{13}$ & - & $\mathrm{X}$ & - & - \\
\hline Barrage Al Mansour Ad-Dahbi ${ }^{(b)}$ & Artificial reservoir & South & - & $\mathrm{X}$ & $\mathrm{X}$ & - & - & $\mathrm{X}$ & $\mathrm{X}$ & - \\
\hline Barrage Al Massira $^{(b)}$ & Artificial reservoir & $\begin{array}{c}\text { Center } \\
\text { Atlantic }\end{array}$ & $\mathrm{X}$ & $\mathrm{X}$ & $\mathrm{X}$ & - & $\mathrm{X}$ & $\mathrm{X}$ & $\mathrm{X}$ & - \\
\hline Barrage de Wad Al Mellah ${ }^{(\mathrm{b})}$ & Artificial reservoir & $\begin{array}{l}\text { Center } \\
\text { Atlantic }\end{array}$ & - & - & $\mathrm{X}$ & - & - & $\mathrm{X}$ & - & - \\
\hline Barrage de Smir ${ }^{(b)}$ & Artificial reservoir & Northwest & $\mathrm{X}^{8}$ & - & - & - & - & $\mathrm{X}$ & - & - \\
\hline Barrage Idriss Premier ${ }^{(b)}$ & Artificial reservoir & Northwest & - & $\mathrm{X}$ & $\mathrm{X}$ & - & - & $\mathrm{X}$ & $\mathrm{X}$ & - \\
\hline Barrage Mohammed $\mathrm{V}^{(\mathrm{b})}$ & Artificial reservoir & Northeast & $\mathrm{X}$ & $\mathrm{X}$ & $\mathrm{X}$ & - & $\mathrm{X}$ & $\mathrm{X}$ & $\mathrm{X}$ & $\mathrm{X}$ \\
\hline Côte et Archipel d'Essawira ${ }^{(c)}$ & Coastal wetland & $\begin{array}{l}\text { Center } \\
\text { Atlantic }\end{array}$ & $\mathrm{X}$ & $\mathrm{X}$ & $\mathrm{X}$ & - & - & $\mathrm{X}$ & $\mathrm{X}$ & - \\
\hline Dayet Ar-Roumi & Inland lake & Northwest & - & - & $\mathrm{X}$ & - & - & $\mathrm{X}$ & - & - \\
\hline Dayet'Awa & Inland lake & Atlas & $\mathrm{X}^{9}$ & - & $\mathrm{X}$ & $\mathrm{I}^{12}$ & $\mathrm{X}$ & $\mathrm{X}$ & $\mathrm{X}$ & $\mathrm{X}$ \\
\hline Dayet Hachlaf & Inland lake & Atlas & $\mathrm{X}^{9}$ & - & - & $\mathrm{I}^{12}$ & $\mathrm{X}$ & $\mathrm{X}$ & - & $\mathrm{X}$ \\
\hline Dayet Ifrah & Inland lake & Atlas & $\mathrm{X}^{9}$ & - & $\mathrm{X}$ & $\mathrm{I}^{12}$ & $\mathrm{X}$ & $\mathrm{X}$ & - & $\mathrm{X}$ \\
\hline Embouchure de Wad Al Wa'er ${ }^{(d)}$ & River mouth & South & - & - & $\mathrm{X}$ & - & - & $\mathrm{X}$ & - & - \\
\hline Embouchure de Wad Assaka ${ }^{(d)}$ & River mouth & South & - & - & $\mathrm{X}$ & - & $\mathrm{X}$ & $\mathrm{X}$ & $\mathrm{X}$ & - \\
\hline Embouchure de Wad Chbeyka ${ }^{(d)}$ & River mouth & South & - & $\mathrm{X}$ & $\mathrm{X}$ & - & $\mathrm{X}$ & $\mathrm{X}$ & $\mathrm{X}$ & - \\
\hline Embouchure de Wad Dr'a ${ }^{\text {(d) }}$ & River mouth & South & $\mathrm{X}$ & - & $\mathrm{X}$ & - & - & - & $\mathrm{X}$ & - \\
\hline Embouchure de Wad Malwiya $a^{(d)}$ & River mouth & Northeast & $\mathrm{X}$ & $\mathrm{X}$ & $\mathrm{X}$ & - & - & $\mathrm{X}$ & $\mathrm{X}$ & $\mathrm{X}$ \\
\hline Embouchure de Wad Martil ${ }^{(d)}$ & River mouth & Northwest & - & $\mathrm{X}$ & - & - & - & $\mathrm{X}$ & - & - \\
\hline Embouchure de Wad Massa ${ }^{(d)}$ & River mouth & South & $\mathrm{X}$ & - & - & $\mathrm{SM}^{14}$ & $\mathrm{X}$ & $\mathrm{X}$ & - & - \\
\hline Lac de Tislite ${ }^{(\mathrm{e})}$ & Inland lake & Atlas & $\mathrm{X}$ & & $\mathrm{X}$ & $\mathrm{HAO}^{15}$ & - & $\mathrm{X}$ & - & - \\
\hline Lac d'Isly ${ }^{(\mathrm{e})}$ & Inland lake & Atlas & & & $\mathrm{X}$ & $\mathrm{HAO}^{15}$ & - & $\mathrm{X}$ & - & - \\
\hline Lagune de Khnifiss ${ }^{(\mathrm{f})}$ & $\begin{array}{l}\text { Lagoon/ } \\
\text { marshland }\end{array}$ & South & $\mathrm{X}$ & $\mathrm{X}$ & $\mathrm{X}$ & $\mathrm{K}^{16}$ & - & - & $\mathrm{X}$ & - \\
\hline $\begin{array}{l}\text { Lagunes de Sidi Moussa- } \\
\text { Walidia }^{(\mathrm{f})}\end{array}$ & $\begin{array}{l}\text { Lagoon/ } \\
\text { marshland }\end{array}$ & $\begin{array}{l}\text { Center } \\
\text { Atlantic }\end{array}$ & $\mathrm{X}$ & $\mathrm{X}$ & $\mathrm{X}$ & - & $\mathrm{X}$ & $\mathrm{X}$ & - & - \\
\hline Marais de Wad Al Maleh ${ }^{(\mathrm{g})}$ & Marshland & $\begin{array}{l}\text { Center } \\
\text { Atlantic }\end{array}$ & $\mathrm{X}$ & - & - & - & - & $\mathrm{X}$ & $\mathrm{X}$ & - \\
\hline Marais de Wad Smir ${ }^{(\mathrm{g})}$ & Marshland & Northwest & $\mathrm{X}^{8}$ & - & - & - & - & $\mathrm{X}$ & $\mathrm{X}$ & - \\
\hline Marais du bas Loukkos ${ }^{(\mathrm{g})}$ & Marshland & Northwest & $\mathrm{X}$ & - & - & - & - & $\mathrm{X}$ & $\mathrm{X}$ & - \\
\hline Merja Al Halloufa & Marshland & Northwest & $\mathrm{X}^{10}$ & $\mathrm{X}$ & $\mathrm{X}$ & - & - & $\mathrm{X}$ & - & - \\
\hline Merja Bargha & Marshland & Northwest & $\mathrm{X}^{10}$ & $\mathrm{X}$ & - & - & - & $\mathrm{X}$ & $\mathrm{X}$ & $\mathrm{X}$ \\
\hline Merja Boukka & Marshland & Northwest & - & - & $\mathrm{X}$ & - & $\mathrm{X}$ & $\mathrm{X}$ & - & - \\
\hline Merja de Fouwarate & Marshland & Northwest & $\mathrm{X}$ & - & $\mathrm{X}$ & - & - & $\mathrm{X}$ & $\mathrm{X}$ & $\mathrm{X}$ \\
\hline Merja de Sidi Bou Ghaba & Marshland & Northwest & $\mathrm{X}$ & $\mathrm{X}$ & $\mathrm{X}$ & - & $\mathrm{X}$ & $\mathrm{X}$ & $\mathrm{X}$ & $\mathrm{X}$ \\
\hline Merja des Wlad Khallouf & Marshland & Northwest & - & - & - & - & $\mathrm{X}$ & $\mathrm{X}$ & - & - \\
\hline Merja des Wlad Skher & Marshland & Northwest & $\mathrm{X}^{10}$ & - & $\mathrm{X}$ & - & - & $\mathrm{X}$ & $\mathrm{X}$ & - \\
\hline Merja Zerga & Marshland & Northwest & $\mathrm{X}$ & $\mathrm{X}$ & $\mathrm{X}$ & - & $\mathrm{X}$ & $\mathrm{X}$ & $\mathrm{X}$ & - \\
\hline Mlalah du Bas Tahaddart & Marshland & Northwest & $\mathrm{X}$ & $\mathrm{X}$ & $\mathrm{X}$ & - & $\mathrm{X}$ & $\mathrm{X}$ & - & - \\
\hline Plan d'eau de Dwiyate ${ }^{(\mathrm{h})}$ & Inland lake & Northwest & - & $\mathrm{X}$ & $\mathrm{X}$ & - & - & $\mathrm{X}$ & $\mathrm{X}$ & $\mathrm{X}$ \\
\hline Plan d'eau de Zerrouqa ${ }^{(h)}$ & Inland lake & Atlas & $\mathrm{X}^{11}$ & - & $\mathrm{X}$ & - & - & $\mathrm{X}$ & - & - \\
\hline Sebkha Bou Areg & Lagoon & Northeast & - & $\mathrm{X}$ & $\mathrm{X}$ & - & $\mathrm{X}$ & $\mathrm{X}$ & $\mathrm{X}$ & - \\
\hline Sebkha Zima & Saline lake & $\begin{array}{l}\text { Center } \\
\text { Atlantic }\end{array}$ & - & $\mathrm{X}$ & $\mathrm{X}$ & - & $\mathrm{X}$ & $\mathrm{X}$ & $\mathrm{X}$ & - \\
\hline Sehb El Mejnoun & $\begin{array}{l}\text { Depression } \\
\text { wetland }\end{array}$ & $\begin{array}{l}\text { Center } \\
\text { Atlantic }\end{array}$ & - & $\mathrm{X}$ & $\mathrm{X}$ & - & - & - & $\mathrm{X}$ & - \\
\hline $\begin{array}{l}\text { Wad As-Saqia Al Hamra à } \\
\text { La'youn }\end{array}$ & River & South & $\mathrm{X}$ & $\mathrm{X}$ & - & - & - & $\mathrm{X}$ & $\mathrm{X}$ & - \\
\hline \multicolumn{11}{|c|}{ 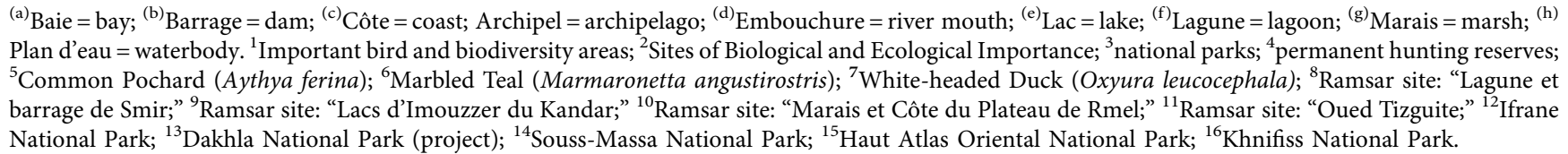 } \\
\hline
\end{tabular}


Morocco is the excessive pumping [31], from artificial and natural wetlands, as well as groundwater. This leads to lower water levels or even the drying-out of the wetlands, making it difficult for the species to thrive in such conditions. The other threats are mainly related to different disturbances that can affect the species population directly (illegal or accidental hunting and stray dogs that feed on ducklings or eggs) or indirectly (recreational activities and inadequate management policies).

Most of the key wintering wetlands of the three waterfowls benefit from at least one conservation status. The attribution of these conservation statuses represents an important step in their conservation. In fact, some of these sites also have management plans that allow enhanced land and water management and the protection against anthropogenic threats. This begs the following question: if the most important sites for the species benefit from conservation statuses and measures, on what scale should we also focus to improve the populations' size?

4.2. Conservation Stakes. For each of three species presented in this article, the population changes are often multifactorial and can be in situ or ex situ. In fact, these ducks are highly dependent on their habitats, especially during the breeding season. As we have discussed above, any negative change, be it natural (e.g., drought and flood) or anthropogenic (e.g., drainage, vegetation cutting, and hydraulic work) can potentially result in their decrease or redistribution to other sites. The designation of Ramsar and important bird and biodiversity sites is one of the important measures for the waterbirds and wetlands conservation and among the good indicators of its success. In Morocco, 49 wetlands are important bird biodiversity areas, 38 are Ramsar sites, and at least 84 are Sites of Biological and Ecological Interest (SBEI), among which many are part of national parks and/or permanent hunting reserves. While these statuses are important, if no ensuing effective management plans are developed and implemented, their degradation, thus their biodiversity's decline, is an inevitable consequence, especially for those subject to many anthropogenic pressures. The Moroccan Department of Water and Forestry has developed management plans for many wetlands: some are finalized, and others are still in progress. The implementation of these plans can face many challenges inherent to the multiplicity of actors involved and the cooperation of the local populations, whose livelihoods may depend on the ecosystem services those wetlands provide. The designation of SBEI in Morocco was a strategic measure and a starting point to prioritize the conservation of the ecosystems with the highest biodiversity indices and hosting the most endangered, rare, or endemic species. But as we have pointed out above, the implementation of management and conservation action plans remains crucial.

On the species' level, the adoption of the National Law $\mathrm{N}^{\circ} 29-05$, enforcing the CITES Convention, is a particularly successful measure deterring all illegal actions threatening endangered species. Furthermore, the national action plan for the White-headed Duck [31] is a crucial step to the conservation of this endangered waterbird and the restoration of a viable population on the long term. Similar actions should be undertaken for the marble teal and the Common Pochard, as well as all globally threatened birds in Morocco, targeting the specific threats for each species in each site. However, efforts must be deployed for a rigorous implementation of these conservation action plans and their evaluation on a regular basis. While the hunting of the White-headed Duck and the Marbled Teal is prohibited, the Common Pochard can still be hunted. Given the current trend of this duck's population, at the national and international levels, more restrictions should be placed on its hunting.

So far, we have discussed the populations' changes inherent to factors at the national level. However, some of these changes can be related to factors at a larger scale and outside the national territory (e.g., threats and conservation measures in other countries). Furthermore, climate change and meteorological conditions can also have an impact on the national population. Kleijn et al. [76] have, for example, reported a positive correlation between waterbirds' population trends in Morocco and precipitations in the Sahel zone that may have a potential impact on birds' migratory strategies. Therefore, some populations' changes are probably more related to shifts in migratory routes and wintering areas than actual changes in birds' numbers [76].

More thorough research could lead to the exact reasons behind the three studied ducks' populations' trends. Comprehensive studies should be conducted to understand the effects of ecological and anthropogenic factors on the distribution, abundance, and population dynamics of waterbirds' species [12], such as water quality, food availability, predation, weather, and conservation statuses. Furthermore, with the increasing challenges that may hinder our monitoring programs [77] and the effectiveness of conservation plans, we must develop new effective methods for waterbirds' census (wintering and breeding populations) with more precision and coverage, coupled with other programs such as ringing-recovery/capturerecapture, continent/flyway, or region-wide series of aerial survey transects as has been suggested by Fox et al. (2019) [77]. This is crucial since the movements occurring within and between the regional populations of the species are still not well understood. Large-scale information on birds' populations' trends and habitats' use is insufficient, which affects negatively the conservation process [78]. Cooperative and coordinated efforts, such as the Mediterranean Waterbirds Network [79], are the key to improve data quality and quantity and to successful and adequate conservation measures, for both waterbirds and wetlands.

\section{Conclusions}

Through this article, we presented the current status of three globally threatened waterfowls' populations in Morocco. While the White-headed Duck's numbers are increasing and the Marbled Teal's are mostly stable, the Common Pochard has known a decline in its wintering population and its breeding range is very limited in the country. 
Another important result of this synthesis is the identification of the Moroccan wetlands that play a major role as hosting key sites of the three species. These results can direct and focus the short-term conservation efforts on these key sites, to enhance the survival and thriving of these species in Morocco.

A better understanding of these ducks' populations' dynamics, which is crucial to prevent their decline, requires further studies on the ecological and anthropogenic factors influencing them. Furthermore, cooperative efforts, coupled with more effective census methods, should be carried out to enhance the knowledge on the species on the flyway/regional levels. These threatened waterbirds' survival depends, in fact, on concerted large-scale conservation measures.

\section{Data Availability}

All data generated or analyzed during this study are included in this article and its supplementary information files.

\section{Disclosure}

The funders and supporting organizations were not involved in this study's proposal, decision to publish, or writing, editing, and approval of the manuscript. The field data used in this study come from the database originating from the yearly campaigns of the waterbirds winter census in Morocco. These campaigns are conducted in the context of the IWC (International Waterbirds census), coordinated by Wetlands International. At the national level, these campaigns and the research studies (on bird species and wetlands), based on the collated data, are conducted as part of the work of the authors at the Study Center for Bird Migration, in the Scientific Institute of Mohammed V University in Rabat, Morocco. The annual campaigns have been coordinated, since 1983, by the Scientific Institute, and in recent years, the NGO "GREPOM/ BirdLife Morocco" has been providing financial and technical support for the field campaigns.

\section{Conflicts of Interest}

The authors declare that there are no conflicts of interest regarding the publication of this paper.

\section{Acknowledgments}

The authors would like to acknowledge the consistent efforts of the observers, national and international, who have relentlessly participated in the waterbirds' winter census that has been conducted regularly in Morocco since 1983. Their commitment is the key that has contributed to a better knowledge for the conservation of waterbirds at the national and international level. The authors greatly appreciate the moral, technical, and financial support of GREPOM/BirdLife Morocco, the Department of Water and Forestry and the Medwaterbirds Network (coordinated by la Tour du Valat). A substantial financial contribution was provided by the ONCFS, through "la Tour du Valat," which coordinates the IWC at the Mediterranean level, and from VBN/Birdlife Netherlands, as a support for GREPOM.

\section{Supplementary Materials}

Table S1. National counts of the Common Pochard's wintering individuals per year and per site. Table S2. National counts of the Marbled Teal's wintering individuals per year and per site. Table S3. National counts of the White-headed Duck's wintering individuals per year and per site. Table S4. List of observers who contributed to the IWC program in Morocco between 1983 and 2019. (Supplementary Materials)

\section{References}

[1] A. El, Gharbaoui (direction) "La grande encyclopédie du Maroc, Volume 3: Géographie physique et géologie, p. 231, Rabat: Les Grandes Editions du Maroc, Rabat, Morocco, 1987.

[2] M. Dakki, M. Menioui, and Z. Amhaouch, "Stratégie nationale et plan d'action 2015-2024 pour les zones Humides du Maroc," 2016.

[3] M. Dakki, (Direction), "La grande encyclopédie du Maroc, Volume 10: Faune”, p. 239, Rabat: Les Grandes Editions du Maroc, Rabat, Morocco, 1988.

[4] M. Thévenot, R. Vernon, and P. Bergier, The Birds of Morocco, BOU, Checklist Series, British Ornithologists' Union, vol. 20, p. 594, Peterborough, Canada, 2003.

[5] T. Fox and T. Stawarczyk, "Pochard Aythya ferina," in The EBCC Atlas of European Breeding Birds, E. J. M. Hagemeijerand and M. J. Blair, Eds., pp. 102-103, Poyser, London, UK, 1997.

[6] BirdLife International, Oxyura leucocephala. The IUCN Red List of Threatened Species 2017, BirdLife International, Cambridge, UK, 2017.

[7] BirdLife International, Marmaronetta Angustirostris (Amended Version of 2016 Assessment). The IUCN Red List of Threatened Species, BirdLife International, Cambridge, UK, 2017.

[8] BirdLife International, Aythya ferina (amended version of 2017 assessment), in The IUCN Red List of Threatened Species, BirdLife International, Cambridge, UK, 2019.

[9] J. Kear, Ducks, Geese and Swans. Volume 2: species accounts (Cairina to Mergus), p. 908, Oxford University Press, Oxford, U.K, 2005.

[10] A. Elafri, M. Belhamra, and M. Houhamdi, "Comparing habitat preferences of a set of waterbird species wintering in coastal wetlands of North Africa: implication for management," Ekológia (Bratislava), vol. 36, no. 2, pp. 158-171, 2017.

[11] P. Bergier, M. Thévenot, A. Rihane, M. A. El Agbani, and A. Qninba, "Liste des oiseaux du Maroc. Mise à jour: mai 2017 (rév. 4.0)," Go-South, vol. 14, pp. 43-68, 2017.

[12] S. I. Cherkaoui, S. Selmi, and S. Hanane, "Ecological factors affecting wetland occupancy by breeding Anatidae in the southwestern mediterranean," Ecological Research, vol. 32, no. 2, pp. 259-269, 2017.

[13] J. Franchimont, F. Fornairon, R. Chalot, and E. K. Mdarhri Alaoui, "L'avifaune du plan d'eau de douyiet (maroc central)," Porphyrio, vol. 2, pp. 5-52, 1990.

[14] M. A. El Agbani, M. Dakki, P. C. Beaubrun, and M. Thévenot, "L'hivernage des Anatidés (Anatidae) au Maroc (1990-1994)," Gibier Faune Sauvage, vol. 13, pp. 233-249, 1996.

[15] M. A. El Agbani, A. Qninba, M. Amezian, F. Cuzin, and M. Dakki, "Le peuplement d'oiseaux d'eau du complexe des zones humides de Smir (Nord du Maroc) ; état actuel et évolution depuis les quatre dernières décennies," Bulletin de l'Institut Scientifique, Rabat, Série Sciences de la Vie, vol. 31, pp. 103-110, 2009. 
[16] I. Cherkaoui, M. Dakki, S. Lahrouz, and S. Hanane, "Dix années de suivi des Anatidés nicheurs sur le lac de Sidi Boughaba (Nord-Ouest Marocain): situation, tendances d'évolution et perspectives de recherche," Revue Écologie (Terre Vie), vol. 68, pp. 167-180, 2013.

[17] S. Lahrouz, M. Dakki, and N. Gmira, "The importance of Fouwarate marshland for wintering and breeding of the threatened ducks' populations in Morocco," Journal of Animal and Plant Sciences, vol. 13, pp. 1800-1810, 2012.

[18] A. J. Green, "The habitat requirements of the Marbled Teal (Marmaronetta angustirostris), Ménétr., a review," in Limnology and Aquatic Birds: Monitoring, Modelling and Management, F. A. Comín, J. A. Herrera, and J. Ramírez, Eds., pp. 147-163, Universidad Autónoma del Yucatán, Mérida, Mexico, 2000.

[19] A. J. Green, The Status and Conservation of the Marbled Teal Marmaronetta Angustirostris, International Waterfowl and Wetlands Research Bureau, Slimbridge, U.K, 1993.

[20] A. J. Green, "Habitat selection by the Marbled Teal Marmaronetta angustirostris, ferruginous duck Aythya nyroca and other ducks in the Göksu Delta, Turkey, in summer," Revue Ecologie (Terre Vie), vol. 53, no. 3, 1998.

[21] A. J. Green and M. E. Hamzaoui, "Diurnal behaviour and habitat use of nonbreeding Marbled Teal," Canadian Journal of Zoology, vol. 78, no. 12, pp. 2112-2118, 2000.

[22] E. Sebastián-González, C. Fuentes, M. Ferrández, J. L. Echevarrias, and A. J. Green, "Habitat selection of Marbled Teal and White-headed Duck during the breeding and wintering seasons in south-eastern Spain," Bird Conservation International, vol. 23, pp. 44-359, 2013.

[23] M. Aourir, A. Qninba, and P. Bergier, "Nidification de la Sarcelle marbrée Marmaronetta angustirostris sur l'Oued Noun-Assaka, Sahara Atlantique marocain," Go-South Bulletin, vol. 13, pp. 43-48, 2016.

[24] M. A. El Agbani, M. Dakki, M. Thévenot, and P.-C. Beaubrun, "Statut actuel au Maroc d'une espèce globalement menacée, la Sarcelle marbrée (Marmaronetta angustirostris)," Bulletin de l'Institut Scientifique, vol. 20, pp. 163-180, 1996.

[25] Y. Zadane, A. Qninba, I. M. Tattou, and P. Bergier, "La daya de Ténouchad, un site de reproduction des Anatidés dans le Parc National de Khnifiss," Go-South Bulletin, vol. 6, pp. 107-112, 2009.

[26] B. Hughes, J. A. Robinson, A. J. Green, Z. W. D. Li, and T. Mundkur (Compilers, International Single Species Action Plan for the Conservation of the White-headed Duck Oxyura leucocephala, CMS Technical Series No. 13 \& AEWA Technical Series No. 8, Bonn, Germany, 2006.

[27] M. I. Sánchez, A. J. Green, and C. Dolz, "The diets of the White-headed Duck Oxyura leucocephala, Ruddy duck O. jamaicensis and their hybrids from Spain," Bird Study, vol. 47, pp. 275-284, 2000.

[28] P. A. Johnsgard and M. Carbonelle, Ruddy Ducks and Other Stifftails, University of Oklahoma Press, Norman, OK, 1996.

[29] P. Bergier, J. Franchimont, and M. Thévenot, "Evolution récente de la population d'Erismature à tête blanche Oxyura leucocephala au Maroc," Alauda, vol. 71, pp. 339-346, 2003.

[30] S. Lahrouz, M. Dakki, and H. Hassani, "Présence d'un effectif remarquable d'Erismatures à tête blanche Oxyura lecocephala dans un marécage du Rharb marocain (Merja de Fouwarate)," Go-South Bulletin, vol. 15, pp. 45-48, 2018.

[31] R. El Hamoumi, A. Ouassou, and M. Dakki, "Plan d'action national pour la conservation de l'Erismature à tête blanche au Maroc," 2017.

[32] C. Bibby, N. Burgess, and D. Hill, Bird Census Techniques, p. 257, 1st edition, Academic Press, London, UK, 1992.
[33] Wetlands International, Guidance on Waterbird Monitoring Methodology: Field Protocol for Waterbird Counting, Wetlands International Publications, New Delhi, India, 2010, https://www.wetlands.org/publications/iwc-guidance-fieldprotocol-for-waterbird-counting/.

[34] M. Dakki, A. Qninba, M. A. El Agbani, A. Benhoussa, and P. C. Beaubrun, "Waders wintering in Morocco: national population estimates, trends and site-assessments," Wader Study Group Bulletin, vol. 96, pp. 47-59, 2001.

[35] M. Dakki, A. Qninba, M. A. El Agbani, and A. Benhoussa, Recensement hivernal d'oiseaux d'eau au Maroc: janvier 19962000, vol. 19, pp. 1-28, Travaux de l'Institut Scientifique, Rabat, Morocco, 2003.

[36] A. Van Strien, J. Pannekoek, W. Hagemeijer, and T. Verstrael, "A loglinear poisson regression method to analyse bird monitoring data," in bird numbers 1995," in Proceedings of the International Conference and 13th Meeting of the European Bird Census Council, A. Anselin, Ed., vol. 13, pp. 33-39, Bird Census News, Pärnu, Parnu, Estonia, 2000.

[37] Wetlands International, Waterbird Population Estimates, Wetlands International Publications, New Delhi, India, 2019.

[38] MAPMDREF Département des Eaux et Forêts, "Arrêté du Ministère de l'Agriculture, de la Pêche Maritime, du Développement Rural et des Eaux et Forêts N6630 du 25 septembre 2019, portant ouverture, clôture et réglementation spéciale de la chasse pendant la saison 2019/2020," 2019.

[39] Ministère de l'Agriculture et de la Mise en Valeur Agricole, "Plan Directeur des aires Protégées du Maroc," BCEOMMontpellier, SECA-Montpellier. Tome 1, vol. 1-5, 1996.

[40] BirdLife International, European Red List of Birds, Office for Official Publications of the European Communities, Luxembourg, Europe, 2015.

[41] A. D. Fox, A. Caizergues, M. V. Banik et al., "Recent changes in the abundance of Common Pochard Aythya ferina breeding in Europe," Wildfowl, vol. 66, pp. 22-40, 2016.

[42] Wetlands International, Flyway Trend Analyses Based on Data from the African-Eurasian Waterbird Census from the Period of 1967-2015, Wetlands International, Lz, Ede, The Netherlands, 2017.

[43] D. A. Scott and P. M. Rose, Atlas of Anatidae Populations in Africa and Western Eurasia, Wetlands International Publication, Wageningen, The Netherlands, 1996.

[44] S. Delany, D. A. Scott, T. Helmink, and G. Martakis, Report on the Conservation Status of Migratory Waterbirds in the Agreement Area, AEWA Technical Series, No. 13, Bonn, Germany, 3rd edition, 2007.

[45] A. Mischenko, A. D. Fox, S. Švažas, O. Sukhanova et al., "Recent changes in breeding abundance and distribution of the Common Pochard (Aythya ferina) in its eastern range," Avian Research, vol. 11, p. 23, 2020.

[46] E. H. Van Nes, R. Noordhuis, E. H. H. R. Lammens et al., "Modelling the effectfs of diving ducks on zebra mussels dreissena polymorpha in lakes," Ecological Modelling, vol. 211, pp. 481-490, 2008.

[47] D. Marchowski, G. Neubauer, Ł. Ławicki et al., "The importance of non-native prey, the zebra mussel Dreissena polymorpha, for the declining greater scaup aythya marila: a case study at a key European staging and wintering site," PLoS One, vol. 10, no. 12, Article ID e0145496, 2015.

[48] D. L. Strayer, B. V. Adamovich, R. Adrian et al., "Long-term population dynamics of dreissenid mussels (Dreissena polymorpha and D. rostriformis): a cross-system analysis," Ecosphere, vol. 104 pages, 2019. 
[49] J. del Hoyo, A. Elliot, and J. Sargatal, Ostrich to Ducks, Vol. 1 of Handbook of the Birds of the World, Lynx Editions, Barcelona, Spain, 1992.

[50] D. M. Evans and K. R. Day, "Hunting disturbance on a large shallow lake: the effectiveness of waterfowl refuges," Ibis, vol. 144, no. 1, pp. 2-8, 2002.

[51] R. Mateo, J. Belliure, J. C. Dolz, J. M. Aguilar-Serrano, and R. Guitart, "High prevalences of lead poisoning in wintering waterfowl in Spain," Archives of Environmental Contamination and Toxicology, vol. 35, no. 2, pp. 342-347, 1998.

[52] B. Folliot, M. Guillemain, J. Champagnon, and A. Caizergues, "Patterns of spatial distribution and migration phenology of Common pochards Aythya ferina in the western palearctic: a ring-recoveries analysis," Wildlife Biology, vol. 1, 2018.

[53] F. Ramírez, C. Rodríguez, J. Seoane, J. Figuerola, and J. Bustamante, "How will climate change affect endangered mediterranean waterbirds?" PLoS One, vol. 13, no. 2, Article ID e0192702, 2018.

[54] M. Žalakevičius and S. Švažas, "Global climate change and its impact on wetlands and waterbird populations," Acta Zoologica Lituanica, vol. 15, no. 3, pp. 211-217, 2005.

[55] T. Jones and W. Cresswell, "The phenology mismatch hypothesis: are declines of migrant birds linked to uneven global climate change?" Journal of Animal Ecology, vol. 79, no. 1, pp. 98-108, 2010.

[56] M. Guillemain, H. Pöysä, A. D. Fox et al., "Effects of climate change on European ducks; what do we know and what do we need to know?” Wildlife Biology, vol. 19, no. 4, pp. 404-419, 2013.

[57] H. Q. P. Crick, "The impact of climate change on birds," Ibis, vol. 146, no. Suppl. 1, pp. 48-56, 2004.

[58] S. Švažas, "Possible impacts of climatic conditions on changes in numbers and in distribution of certain breeding and staging wildfowl species in lithuania," Acta Zoologica Lituanica, vol. 11, no. 2, pp. 163-182, 2012.

[59] A. J. Green, "International action plan for the Marbled Teal (Marmaronetta angustirostris),", in Globally Threatened Birds in Europe: Action Plans, B. Heredia, L. Rose, and M. Painter, Eds., pp. 99-117, Council of Europe, and BirdLife International, Strasbourg, France, 1996.

[60] M. Aberkane, M.-C. Maazi, F. Chettibi, E.-Y. Guergueb, Z. Bouslama, and M. Houhamdi, "Dirunal wintering behavior of the Marbled Teal (Marmaronetta angustirostris) in northeast Algeria," Zoology and Ecology, vol. 24, no. 1, pp. 10-15, 2014.

[61] A. Bouzegag, M. Saheb, E. Bensaci, Y. Nouidjem, and M. Houhamdi, "Ecologie de la Sarcelle Marbrée Marmaronetta angustirostris (Ménétries, 1832) dans l'éco-complexe de zones humides de la vallée de l'oued Righ (Sahar Algérien)," Bulletin de l'Institut Scientifique, Rabat, Section Sciences de la Vie, vol. 35, pp. 141-149, 2013.

[62] M. Aberkane, F. Chettibi, B. Bakhouche, K. Draidi, Z. Bouslama, and M. Houhamdi, "Breeding ecology of the marbled duck Marmaronetta angustirostris at boussedra march (annaba, northeast of Algeria)," Annals of Biological Research, vol. 4, no. 10, pp. 103-107, 2013.

[63] A. Iñigo, B. Barov, C. Orhun, and U. Gallo-Orsi, Species Action Plan for the Marbled Teal Marmaronetta Angustirostris in the European Union, BirdLife International for the European Commission, Zeist, Netherlands, 2008.

[64] A. J. Green, M. El Hamzaoui, M. El Agbani, and J. Franchimont, "The conservation status of Moroccan wetlands with particular reference to waterbirds and to changes since 1978," Biological Conservation, vol. 104, pp. 71-82, 2002.
[65] S. I. Cherkaoui, N. Mgari, and S. Hanane, "Factors predicting Ramsar site occupancy by threatened waterfowl: the case of the Marbled Teal Marmaronetta angustirostris and Ferruginous duck Aythya nyroca in Morocco," Ardeola, vol. 63, no. 2, pp. 295-309, 2016.

[66] R. Sheldon, N. Mikander, and J. Fernández, Orueta (Compilers), "International Single Species Action Plan for the Conservation of the White-headed Duck (Oxyura leucocephala), AEWA Technical Series No. XX, Bonn, Germany, 1st edition, 2018.

[67] N. Meziane, F. Samraoui, and B. Samraoui, "Status and diurnal activity budget of non-breeding White-headed Ducks Oxyura leucocephala in Algeria," Ostrich: Journal of African Ornithology, vol. 85, no. 2, 2014.

[68] F. Chettibi, R. Khelifa, M. Aberkane, Z. Bouslama, and M. Houhamdi, "Diurnal activity budget and breeding ecology of the White-headed Duck Oxyura leucocephala at lake Tonga (North-East Algeria)," Zoology and Ecology, vol. 23, pp. 183-190, 2013.

[69] A. Lazli, A. Boumezbeur, N. Moali-Grine, and A. Moali, "Évolution de la population nicheuse de l'Erismature à tête blanche Oxyura leucocephala sur le lac Tonga (Algérie)," Revue Ecologie (Terre Vie), vol. 66, 2011.

[70] S. Metallaoui, S. Atoussi, A. Merzoug, and M. Houhamdi, "Hivernage de l'Erismature à tête blanche (Oxyura leucocephala) dans Garaet Hadj-Tahar (Skikda, nord-est de l'Algérie)," Aves, vol. 46, no. 3, pp. 136-140, 2009.

[71] A. Laure-Brochet, W. van den Bossche, S. Jbour et al., "Preliminary assessment of the scope and scale of illegal killing and taking of birds in the Mediterranean," Bird Conservation International, vol. 26, pp. 1-28, 2016.

[72] B. Hughes, J. Criado, S. Delany et al., The Status of the North American Ruddy Duck (Oxyura jamaicensis) in the Western Palearctic: Towards an Action Plan for Eradication, Wildfowl \& Wetlands Trust, Newtownards, UK, 1999.

[73] Haut Commissariat aux Eaux et Forêts et à la lutte contre la désertification du Maroc, "Plan d'action contre l'Erismature rousse au Maroc 2003-2005,” 2003.

[74] Z. Nouaceur and O. Mur arescu, "Rainfall variability and trend analysis of annual rainfall in North Africa," International Journal of Atmospheric Sciences, vol. 2016, Article ID 7230450, 12 pages, 2016.

[75] A. Ouassou, M. Dakki, and M. A. El Agbani, Recensement hivernal d'oiseaux d'eau au Maroc: 2011-2015, Travaux de l'Institut Scientifique, Rabat, Série Zoologie, 2017.

[76] D. Kleijn, I. Cherkaoui, P. W. Goedhart, J. Van Der Hout, and D. Lammertsma, "Waterbirds increase more rapidly in ramsar-designated wetlands than in unprotected wetlands," Journal of Applied Ecology, vol. 51, pp. 289-298, 2014.

[77] A. D. Fox, R. D. Nielsen, and I. K. Petersen, "Climate change not only threatens bird populations but also challenges our ability to monitor them," Ibis, vol. 161, pp. 467-474, 2019.

[78] N. C. Davidson and D. A. Stroud, "African-Western Eurasian flyways: current knowledge, population status and future challenges," in Proceedings of the Waterbirds Around the World, G. C. Boere, C. A. Galbraith, and D. A. Stroud, Eds., The Stationery Office, Edinburgh, UK, pp. 63-73, March 2006.

[79] M. S. Sayoud, H. Salhi, B. Chalabi et al., "The first coordinated trans-North African mid-winter waterbird census: the contribution of the international waterbird census to the conservation of waterbirds and wetlands at a biogeographical level," Biological Conservation, vol. 206, pp. 11-20, 2017. 